\title{
Curcumin activates the p38MPAK-HSP25 pathway in vitro but fails to attenuate diabetic nephropathy in DBA2J mice despite urinary clearance documented by HPLC
}

Jun $\mathrm{Ma}^{\dagger}$, Lynetta Phillips ${ }^{\dagger}$, Ying Wang, Tiane Dai, Janine LaPage, Rama Natarajan, Sharon G Adler

\begin{abstract}
Background: Curcumin has anti-inflammatory, anti-oxidant, and anti-proliferative properties, and depending upon the experimental circumstances, may be pro- or anti-apoptotic. Many of these biological actions could ameliorate diabetic nephropathy.

Methods/Design: Mouse podocytes, cultured in basal or high glucose conditions, underwent acute exposure to curcumin. Western blots for p38-MAPK, COX-2 and cleaved caspase-3; isoelectric focusing for HSP25 phosphorylation; and DNase I assays for F- to G- actin cleavage were performed for in vitro analyses. In vivo studies examined the effects of dietary curcumin on the development of diabetic nephropathy in streptozotocin (Stz)induced diabetes in DBA2J mice. Urinary albumin to creatinine ratios were obtained, high performance liquid chromatography was performed for urinary curcuminoid measurements, and Western blots for p38-MAPK and total HSP25 were performed.

Results: Curcumin enhanced the phosphorylation of both p38MAPK and downstream HSP25; inhibited COX-2; induced a trend towards attenuation of F- to G-actin cleavage; and dramatically inhibited the activation of caspase3 in vitro. In curcumin-treated DBA2J mice with Stz-diabetes, HPLC measurements confirmed the presence of urinary curcuminoid. Nevertheless, dietary provision of curcumin either before or after the induction of diabetes failed to attenuate albuminuria.

Conclusions: Apart from species, strain, early differences in glycemic control, and/or dosing effects, the failure to modulate albuminuria may have been due to a decrement in renal HSP25 or stimulation of the 12/15 lipoxygenase pathway in DBA2J mice fed curcumin. In addition, these studies suggest that timed urine collections may be useful for monitoring curcumin dosing and renal pharmacodynamic effects.
\end{abstract}

\section{Background}

Diabetic nephropathy (DN) remains the commonest cause of end stage renal disease. Albuminuria, the cardinal clinical feature of DN, is induced by mechanisms undergoing reappraisal [1], but which primarily involve podocyte pathology, along with alterations in the glomerular basement membrane (GBM), endothelium, mesangium, and renal tubule cells [2-8]. Podocyte effacement is

\footnotetext{
* Correspondence: sadler@labiomed.org

† Contributed equally

Los Angeles Biomedical Research Institute at Harbor-UCLA Medical Center, Division of Nephrology and Hypertension, 1124 W Carson St, Torrance, CA 90502, USA
}

closely aligned with albuminuria and reflects, at least in part, actin cytoskeletal rearrangement.

Heat shock proteins (HSP) are ubiquitously expressed across virtually all phyla. Classified by molecular weight, HSPs influence key biological processes such as cell division and cell survival [9], differentiation, actin cytoskeleton regulation, and resistance to injury from reactive oxygen species (ROS), and other cell stressors [10]. HSP25, the rodent homolog of human HSP27, is phosphorylated by upstream p38 mitogen-activated protein kinase (p38MAPK). Phosphorylated HSP25 plays a key role in the regulation of actin cytoskeletal dynamics 
[11-17]. We previously showed in vitro that short-term incubation of podocytes in medium with a high glucose concentration (up to 4 hours) resulted in phosphorylation of p38MAPK and downstream HSP25, associated with maintenance of the actin cytoskeleton. Incubation of podocytes in high glucose medium for as briefly as 4 hours with a p38MAPK inhibitor attenuated downstream HSP25 phosphorylation, inducing F- to G-actin cleavage, and cytoskeletal disruption. We previously showed in vitro that short-term incubation of podocytes in medium with a high glucose concentration resulted in phosphorylation of p38MAPK and downstream HSP25, associated with maintenance of the actin cytoskeleton. Incubation of podocytes in high glucose medium for hours, or incubation with a p38MAPK inhibitor, attenuated downstream HSP25 phosphorylation, inducing F- to G-actin cleavage, and cytoskeletal disruption. In vivo, we showed that acutely after the induction of diabetes with streptozotocin (Stz-DM) in rats, there is coordinated activation of the glomerular p38MAPKHSP25 pathway, in association with maintenance of the podocyte actin cytoskeleton and normoalbuminuria. However, with chronicity of Stz-DM, pathway activation declines, F-actin cleavage generates G-actin monomers, and podocyte effacement and albuminuria occur [18]. These associations generated the hypothesis that early activation of the p38MAPK-HSP25 pathway might be a functional adaptation that maintained podocyte structure and function and prevented albuminuria in response to the glucose stressor. Based on these observations, we posited that therapies that prolonged the activation of the p38MAPK-HSP25 pathway would attenuate albuminuria.

Curcumin (diferuloylmethane) is one of the most commonly used spices in the world. In numerous cell types, exposure to curcumin has been shown to increase HSPs in vitro [14-17,19-22]. We performed experiments to determine whether curcumin activates the p38MAPK -HSP25-actin cytoskeletal pathway in glucose-stimulated podocytes in vitro, and whether it attenuates diabetic nephropathy (DN) in vivo in mice in whom feeding was begun either before or 1 week after the induction of Stz-DM.

\section{Methods \& Design Podocyte Culture}

Conditionally immortalized mouse podocytes (Pods), carrying a thermosensitive SV40 transgene, were obtained from Dr. Peter Mundel and cultured as described with minor modifications [23]. Briefly, PODs proliferated at $33^{\circ} \mathrm{C}$ (permissive conditions) in RPMI 1640 media supplemented with $5.5 \mathrm{mM}$ glucose, $10 \%$ fetal bovine serum (FBS), $\gamma$-IFN (tapered from $50 \mathrm{U} / \mathrm{ml}$ to $10 \mathrm{U} / \mathrm{ml}$ ), and $1 \%$ penicillin/streptomycin/amphotericin B (Invitrogen,
Carlsbad, CA). Pods were grown in collagen-coated flasks in a humidified atmosphere of $95 \%$ air and $5 \% \mathrm{CO}_{2}$. Cells were then thermoshifted to $37^{\circ}$ and allowed to differentiate for 14 days without $\gamma$-IFN (nonpermissive conditions) with media changed on alternate days. Pods between 4-8 passages were used for all experiments.

Cells were serum starved in RPMI with $0.4 \%$ FBS for $24 \mathrm{~h}$. Dose and time-course experiments were performed to determine optimal conditions for the experiments. Curcumin (Cur, generously donated by Sabinsa Corporation, Piscataway, NJ) was dissolved in $100 \%$ ethanol at a stock concentration of $10 \mathrm{mM}$ and further diluted to experimental concentrations ranging from 1 $\mu \mathrm{M}$ to $100 \mu \mathrm{M}$ in RPMI. In dose-response preliminary in vitro studies, $30 \mu \mathrm{M}$ Cur demonstrated the most robust HSP25 signaling activation and was used for all experiments. Cur at $100 \mu \mathrm{M}$ induced cell death (data not shown). The effects of Cur on the phosphorylated p38 mitogen-activated protein kinase (pp38MAPK) phosphorylated HSP25/27 (pHSP25/27) signaling pathway in the presence and absence of glycemic stress were assessed with the following treatment groups: 1) 5.5 $\mathrm{mM}$ glucose for 60-70 min (normal glucose, NG); 2) 5.5 $\mathrm{mM}$ glucose with $30 \mathrm{uM}$ Cur for 60-70 min (NG+Cur); 3) $5.5 \mathrm{mM}$ glucose for $60 \mathrm{~min}$ immediately replaced by $30 \mathrm{mM}$ glucose for $10 \mathrm{~min}$ (high glucose, HG); 4) 5.5 $\mathrm{mM}$ glucose with $30 \mu \mathrm{M}$ Cur for 60 min immediately replaced by $30 \mathrm{mM}$ glucose with $30 \mu \mathrm{M}$ Cur for $10 \mathrm{~min}$ (HG+Cur); and 5) $5.5 \mathrm{mM}$ glucose + mannitol to achieve iso-osmolarity $(5.5+24.5 \mathrm{mM})(\mathrm{NG}+\mathrm{M})$. The $\mathrm{HG} / \mathrm{Cur}$ treatment used in isoelectric focusing was performed under the following conditions: $5.5 \mathrm{mM}$ glucose with $30 \mu \mathrm{M}$ Cur for $60 \mathrm{~min}$ immediately replaced by 30 $\mathrm{mM}$ glucose for $10 \mathrm{~min}$. Published work from our lab [18] showed that HG for $10 \mathrm{~min}$ induced significant increases in pp38MAPK and pHSP25 in Pods. Thus, a 10 min HG treatment period was used in the current study. Cells were harvested in RIPA or urea buffer (see below) following treatments.

\section{Western Blot Analysis}

Following experimental treatments, cells were washed with ice cold phosphate-buffered saline (PBS) and harvested in RIPA buffer $(1 \times$ PBS, $1 \%$ nonidet P-40, $0.5 \%$ sodium deoxycholate, $0.1 \%$ sodium dodecyl sulfate, 20 $\mathrm{mM}$ sodium fluoride) with proteinase and phosphatase inhibitor cocktails 1 and 2 (Sigma-Aldrich, St Louis, MO, USA). Cells were sonicated, centrifuged at 10,000 $\times$ $g$ for $10 \mathrm{~min}$ at $4^{\circ} \mathrm{C}$, and cell lysates stored at $-20^{\circ} \mathrm{C}$ until use. Protein concentration in cell lysate was measured using Protein Assay Dye Reagent (Bio-Rad Laboratories, Hercules, CA) and known bovine serum albumin (BSA) concentrations as standards. Supernatants containing 50-100 $\mu$ g protein were loaded onto $7-15 \%$ gradient 
sodium dodecyl sulfate (SDS)-polyacrylamide gels. Following electrophoresis, proteins were transferred overnight onto nitrocellulose membranes (GE Osmonics Labstore, Minnetonka, MN) and blocked with 5\% milk or $5 \%$ BSA in tris-buffered saline solution with $0.2 \%$ Tween 20.

Membranes were probed with the following antibodies: HSP25 (Stressgen, Victoria, BC, Canada), total p38MAPK, phospho-p38MAPK and cleaved caspase-3 (Cell Signaling Technology, Inc. Danvers, MA, USA), cyclooxygenase-2 (COX-2)(Santa Cruz Biotechnology, Santa Cruz, CA, USA), glyceradehyde-3-phosphate dehydrogenase (GAPDH, Fitzgerald Industries International, Inc., Concord, MA, USA), goat anti-mouse IgG (Santa Cruz Biotechnology), goat anti-rabbit IgG (Cell Signaling Technology, Inc.) and mouse anti-goat IgG (Santa Cruz Biotechnology). Western blots were incubated in commercial enhanced chemiluminescence reagents (Pierce Biotechnology, Inc., Rockford, IL) and exposed to photographic film. Densitometry was quantified using AlphaDigiDoc 1000 software (Alpha Innotech Corporation, San Leandro, CA).

\section{Isoelectric Focusing for HSP25}

Isoelectric focusing (IEF) was performed to measure concentrations of phosphorylated HSP25 as described previously $[2,3]$. All samples for IEF were solubilized in urea buffer $(9 \mathrm{M}$ urea, $2 \%$ nonidet $\mathrm{P}-40,0.005 \% \beta$-mercaptoethanol) at the time of cell harvesting and stored at $-20^{\circ} \mathrm{C}$ until use.

\section{DNase 1 inhibition assay for the measurement of F/G actin ratio}

Pod F- and G-actin were measured using the methods of others [24,25] and as we previously utilized [18]. Once solubilized in lysis buffer, lysate was added to DNAse I solution $(0.1 \mathrm{mg} / \mathrm{mL}$ bovine pancreas DNase I in $50 \mathrm{mM}$ Tris $/ \mathrm{HCl}, 10 \mathrm{mM}$ phenylmethylsulfonyl fluoride, $\left.0.5 \mathrm{mM} \mathrm{CaCl}_{2}, \mathrm{pH} 7.5\right)$ and DNA solution $(40 \mu \mathrm{g} /$ $\mathrm{mL}$ calf thymus DNA type 1 in $100 \mathrm{mM}$ Tris/ $\mathrm{HCl}$, $4 \mathrm{mM} \mathrm{MgSO}_{4}, 1.8 \mathrm{mM} \mathrm{CaCl}_{2}$, pH 7.5). DNase I activity was monitored at $260 \mathrm{~nm}$. Actin was measured using a standard curve for inhibition of DNase I activity using rabbit skeletal muscle G-actin (Sigma-Aldrich). Linearity was established between 25 and $70 \%$ inhibition of DNase I activity. For total actin, lysates were diluted with lysis buffer and incubated on ice with an equal volume of guanidine/ $\mathrm{HCl}$ buffer to depolymerize $\mathrm{F}$-actin to monomeric G-actin. F-actin was calculated as the difference between total and G-actin.

\section{Experimental Animals}

Diabetes mellitus (DM) was induced in male 20-22 gm two-month old DBA/2J mice (Jackson Laboratories,
Bar Harbor, Maine, USA) by injecting a daily dose of streptozotocin (Stz, $50 \mathrm{mg} / \mathrm{kg}$, i.p., prepared in $0.05 \mathrm{M}$ sodium citrate buffer) for 5 consecutive days. Agematched control mice received only sodium citrate buffer. Diabetes was confirmed by fasting blood glucose levels one week after the $5^{\text {th }}$ daily Stz injection. Control and DM mice were placed on custom-prepared diets (Purina Mills LLC TestDiet ${ }^{\circ}$ Division, Richmond, IN) that differed only in Cur content. The diet compositor, and initial dosing assignments, were chosen based on the prior experience of the Purina Mills LLC Test Diet Division, who prepared identical diets for a therapeutically successful study using Cur for a mouse model of Alzheimer disease [26]. Two studies were performed. In Experiment 1, Cur feeding at 5,000 ppm ( $\left.\mathrm{Cur}_{5,000 \mathrm{ppm}}\right)$ began one week after the last Stz injection, at the time the diagnosis of DM was confirmed. Due to the inability to show benefit from Cur in Experiment 1, in Experiment 2, pre-feeding of $\mathrm{Cur}_{5,000 \mathrm{ppm}}$ or $\mathrm{Cur}_{7,500 \mathrm{ppm}}$ was begun prior to DM induction by Stz injections.

In Experiment 1, non-diabetic (noDM) or DM mice were assigned to one of the following diets at the time the DM was confirmed in the Stz-injected group (Day $0)$ : 1) control chow with $0 \mathrm{ppm}$ Cur ( $\mathrm{n}=8$ for noDM$\mathrm{Cur}_{0} ; \mathrm{n}=11$ for $\mathrm{DMCur}_{0}$ ); 2) test chow with $\mathrm{Cur}_{5,000}$ $\mathrm{ppm}\left(\mathrm{n}=10\right.$ for noDMCur $5000 ; \mathrm{n}=6$ for $\left.\operatorname{DMCur}_{5000}\right)$. For each mouse, food and water intake were measured. On days 9 and 15 of the study, mice were placed in individual metabolic cages with 5\% dextrose in water for an overnight collection to measure urinary albumin (ELISA Albuwell M Kit Stock no. 1011, Exocell Inc., Philadelphia, PA), creatinine (Creatinine Companion Stock no. 1012, Exocell Inc., Philadelphia, PA), the arachidonic acid metabolite 12-hydroxytetraenoic acid (12HETE), and Cur and its metabolites by high performance liquid chromatography (HPLC). For urine albu$\mathrm{min} / \mathrm{creatinine}$ ratio, data was expressed as $\log _{10}$ in order to achieve a normal distribution.

In Experiment 2, mice were randomly assigned to receive a control or Cur diet one week prior to Stz injections. Mice were then injected with Stz daily for 5 days as described above. DM was ascertained one week after the last Stz injection (Day 0), and then again in steady state from weeks 5-7, and in some mice specially maintained for glycemic monitoring, up to 11 weeks. The following experimental conditions were compared: 1) control chow with $0 \mathrm{ppm}$ Cur $\left(\mathrm{n}=5\right.$ for noDMCur ${ }_{0}$; $\mathrm{n}=5$ for $\left.\mathrm{DMCur}_{0}\right)$; 2) test chow with $\mathrm{Cur}_{5,000} \mathrm{ppm}(\mathrm{n}=$ 6 for noDMCur ${ }_{5000}, \mathrm{n}=7$ for $\left.\mathrm{DMCur}_{5000}\right)$; or 3 ) test chow $\operatorname{Cur}_{7,500 \mathrm{ppm}}(\mathrm{n}=6$ for noDM Cur $7500 ; \mathrm{n}=5$ for DMCur $_{7500}$ ). Timed urine collections were made on weeks 2,4 , and 7 for urine albumin and creatinine measurements. All studies were performed under a protocol approved by the Los Angeles Biomedical Research 
Institute Animal Use Committee. Mice were sacrificed by exsanguination under general anesthesia.

\section{Measurement of Urinary 12-HETE and Cur}

Urinary 12-HETE was measured by enzyme immunoassay (12-HETE EIA, 12(S)-HETE Correlate EIA Kit Catalog no. 900-050, Assay Designs Inc., Ann Arbor, MI). Cur and its metabolites (total curcuminoid) were measured at the Nutrition Core Research Laboratory at the University of California at San Diego using HPLC at a wavelength of $262 \mathrm{~nm}$ by methods similar to those previously reported [27]. However, an interfering background peak that co-eluted with urine total curcuminoid at $262 \mathrm{~nm}$ was identified. The mean OD values measured at $262 \mathrm{~nm}$ from the urine of mice receiving control diet $\mathrm{Cur}_{0}$ were subtracted from the urine results from mice receiving Cur in the diet in order to compensate for the presence of the interfering substance.

\section{Statistical Analysis}

Analysis of variance followed by Student's $t$ test was utilized for analysis of all results. Statistical calculations were performed using StatMost (Salt Lake City, UT). Data are expressed as mean \pm SEM. Significance is assigned at the $\mathrm{p}<0.05$ level.

\section{Results and discussion}

\section{Cur stimulates phosphorylation of p38MAPK and HSP25} in cultured podocytes

The ability of Cur to stimulate phosphorylation of p38MAPK and HSP25 in both normal glucose (NG, $5.5 \mathrm{mM}$ ) and high glucose ( $\mathrm{HG}, 30 \mathrm{mM})$ media was assessed. To determine optimal experimental conditions, a pilot dose-dependent titration experiment was performed exposing Pods to Cur concentrations ranging from 1-100 $\mu \mathrm{M}$. $30 \mu \mathrm{M}$ Cur (Cur $30 \mu \mathrm{M}$ ) stimulated total HSP2 5 protein expression the most (data not shown) and was therefore used for all subsequent experiments. A time-dependent titration further demonstrated that treating cells with Cur for 60-70 min stimulated HSP25 protein expression (data not shown). Our published work showed that incubating Pods in HG for up to 24 hrs stimulated the phosphorylation of p38MAPK and HSP25 while maintaining the actin cytoskeleton [18]. We performed all subsequent experiments under the conditions selected from these initial studies. Mannitol served as an iso-osmotic control.

Cur significantly increased podocyte pp38MAPK 1.8fold when added to NG media $\left(\mathrm{NG}+\mathrm{Cur}_{30 \mu \mathrm{M}}, 1.77 \pm\right.$ 0.10 vs. NG, $1.00 \pm 0.02$; $\mathrm{P}<0.01$; Figure $1 \mathrm{a}$ ). As anticipated, podocyte pp38MAPK was significantly higher in HG compared to NG, but $\mathrm{Cur}_{30 \mu \mathrm{M}}$ further increased pp38MAPK even when added to HG $(1.76 \pm 0.13$ versus
$1.38 \pm 0.03 ; \mathrm{P}<0.05)$. Thus, when added to either NG or HG, Cur $30 \mu \mathrm{M}$ exposure further increased p38MAPK activation by a similar degree. Mannitol did not replicate the p38MAPK activation induced by HG, indicating an effect occurring independent of osmolarity.

Activation of p38MAPK phosphorylates downstream HSP25/27. Thus, podocyte exposure to $\mathrm{Cur}_{30} \mu \mathrm{M}$ induced HSP25 biphosphorylation as demonstrated by isoelectric focusing (IEF) (Figure 1b). $\mathrm{Cur}_{30 \mu \mathrm{M}}$, when added to NG, significantly increased the biphosphorylated HSP25/total HSP25 ratio by $\sim 1.5$-fold $(1.00 \pm 0.07$ (NG) vs. $1.47 \pm 0.11\left(\mathrm{NG}+\mathrm{Cur}_{30 \mu \mathrm{M}}\right), \mathrm{P}<0.01$; Figure 1b). As anticipated, the biphosphorylated HSP25/total HSP25 ratio also significantly increased when $\mathrm{Cur}_{30 \mu \mathrm{M}}$ was added to HG medium (1.28 \pm 0.07 (HG) vs $1.86 \pm$ 0.061(HG+ $\left.\left.\mathrm{Cur}_{30 \mu \mathrm{M}}\right), \mathrm{P}<0.05\right)$. Mannitol did not affect pHSP25 phosphorylation (data not shown).

Curcumin's effect on the preservation of Pod actin cytoskeleton was directly examined (Figure 1c). There was a trend towards increased filamentous to monomeric globular actin ratio (F/G-actin) in Pods receiving Cur (1.8-fold in NG, 1.3-fold in HG). These increases in F/G-actin fell short of statistical significance. Collectively, these data demonstrate that Cur activates the Pod p38MAPK-HSP25 signaling pathway by phosphorylation in vitro under both NG and HG conditions.

\section{Cur prevents caspase-3 activation and inhibits COX-2 expression}

When podocytes were harvested immediately after a 1hr exposure to $\mathrm{Cur}_{30 \mu \mathrm{M}}$, activation of caspase-3 was attenuated to levels significantly below those observed in the control NG conditions (1.00 \pm 0.04 (NG) vs. 0.57 $\pm 0.02\left(\mathrm{NG}+\mathrm{Cur}_{30 \mu \mathrm{M}}\right) ; \mathrm{P}<0.01$; Figure 2a). This inhibition was even more pronounced in HG media (1.18 \pm 0.01 (HG) vs. $\left.0.22 \pm 0.03\left(\mathrm{HG}+\mathrm{Cur}_{30 \mu \mathrm{M}}\right) ; \mathrm{P}<0.02\right)$. Similar results were observed for the effect of $\mathrm{Cur}_{30} \mu \mathrm{M}$ on COX-2 expression (Figure 2b) (COX-2, (1.00 \pm 0.08 (NG) vs. $\left.\left.0.20 \pm 0.05\left(\mathrm{NG}+\mathrm{Cur}_{30 \mu \mathrm{M}}\right) ; \mathrm{P}<0.01\right)\right)$. Cur had a greater effect on COX-2 inhibition in HG than NG media, (COX-2, $1.00 \pm 0.18$ (HG) vs. $0.05 \pm 0.004$ $\left.\left.\left(\mathrm{HG}+\mathrm{Cur}_{30 \mu \mathrm{M}}\right) ; \mathrm{P}<0.01\right)\right)$.

\section{The effect of Cur feeding on DN as measured by urine albumin/creatinine (Ualb/cr) ratio}

Diets with Cur or identical control diets without Cur were fed to noDM mice and mice with DM beginning one week after the last Stz injection (Experiment 1). Ualb/cr was measured as an indicator of the development and severity of DN. Blood glucose in the six experimental groups one week after the last Stz injection were not different and are summarized in Figure 3a. Ualb/cr was measured after 9 and 15 days on the various diets. Since similar levels of Ualb/cr were present 

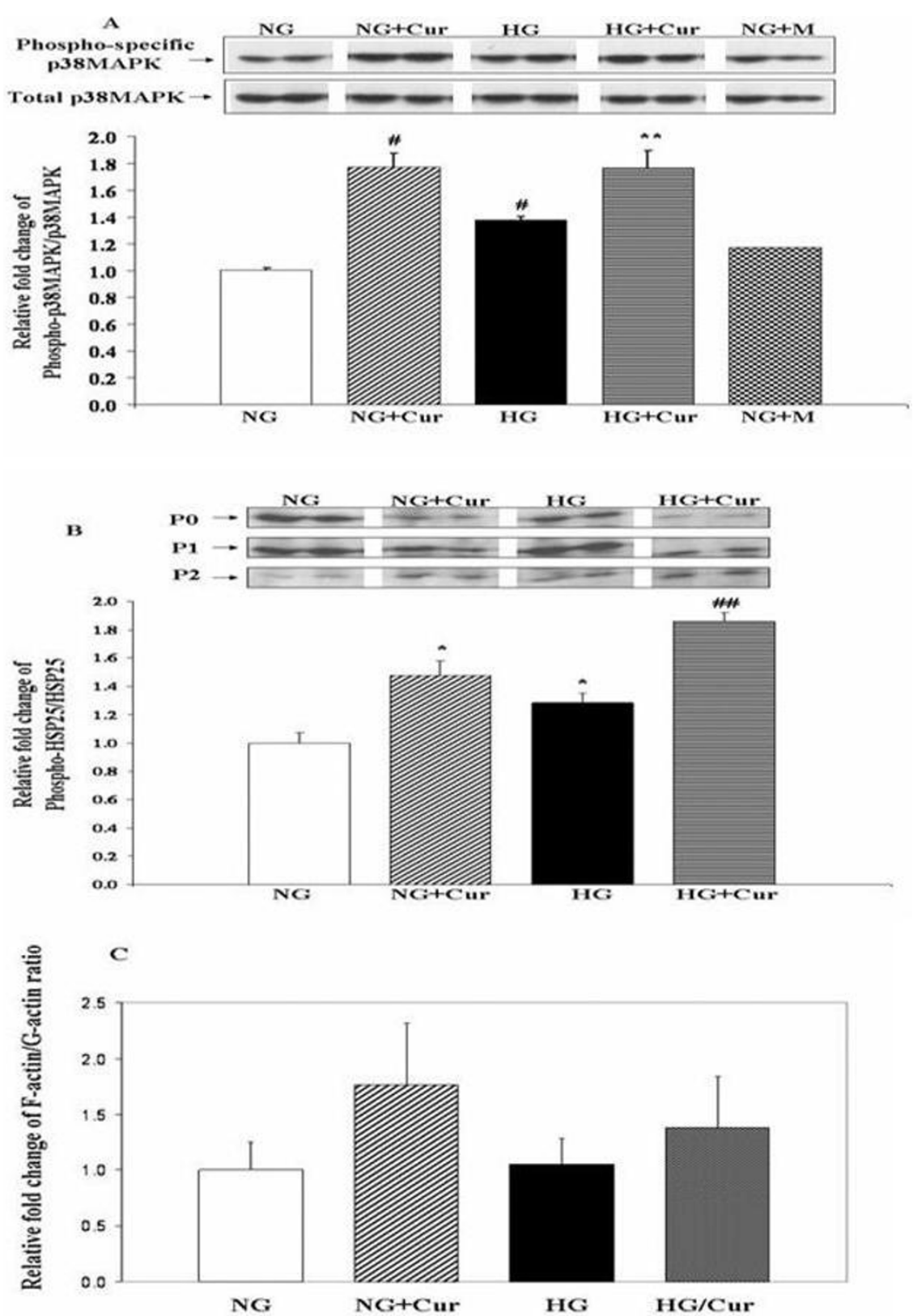

Figure 1 Curcumin activates p38MAPK and phosphorylates HSP25 in cultured Pods. $5.5 \mathrm{mM}$ glucose (NG), $5.5 \mathrm{mM}$ glucose+30 $\mu \mathrm{M}$ curcumin (NG+Cur), $30 \mathrm{mM}$ glucose $(\mathrm{HG}), 30 \mathrm{mM}$ glucose+30 $\mu \mathrm{M}$ curcumin ( $\mathrm{HG}+\mathrm{Cur}), 5.5 \mathrm{mM}$ glucose+24.5 mM mannitol (NG+M). (a) Representative Western blots of phospho-specific p38MAPK (pp38MAPK) and quantitative evaluation of pp38MAPK relative to total p38MAPK (p38MAPK) by densitometric analysis. (b) Representative IEF separating total HSP25 into its nonphosphorylated isoform (P0), mono- (P1), and biphoshorylated (P2) isoforms, Western blots of HSP25, and quantitative evaluation of relative phosphorylated HSP25 isoforms to total HSP25 ((P1 $+\mathrm{P} 2) /(\mathrm{P0}+\mathrm{P} 1+\mathrm{P} 2))$ by densitometry analysis. Mannitol values $(\mathrm{n}=2)$ are not displayed but were similar to NG. (c) DNAse I assay of F-actin/Gactin ratios. All data expressed as mean \pm SEM $(n=3)$. ${ }^{*} P<0.05$ compared with NG; \#P $<0.01$ compared with NG; **P $<0.05$ compared with $H G$; \#\# < 0.01 compared with HG.

in the diabetic mice at 9 and 15 days, pooled data from these two time points are provided (Figure $3 b$ ). As expected, Ualb/cr excretion $\left(\log _{10}\right)$ was higher in $\mathrm{DM}_{\text {Cur0 }}$ than noDM $\mathrm{Cur0}_{\text {C }}$ mice $(2.23 \pm 07$ vs1.93 \pm 0.11 , respectively; $\mathrm{P}<0.05)$, even at this early time point. (Original Ualb/cr measure was $\mu \mathrm{g} / \mathrm{mg}$ ). However, In
$\mathrm{DM}_{\text {Cur500o }}$ mice, Cur did not lower Ualb/cr. Ualb/cr excretion in $\mathrm{DM}_{\text {Cur5000 }}$ mice was actually higher (2.41 \pm 0.09) than $\mathrm{DM}_{\text {Cur0 }}$ mice $(2.00 \pm 0.09 ; \mathrm{P}<0.05)$.

Since the feeding regimen in Experiment 1 failed to lower Ualb/cr, we performed Experiment 2, in which Cur feeding preceded Stz DM-induction. In addition, to 


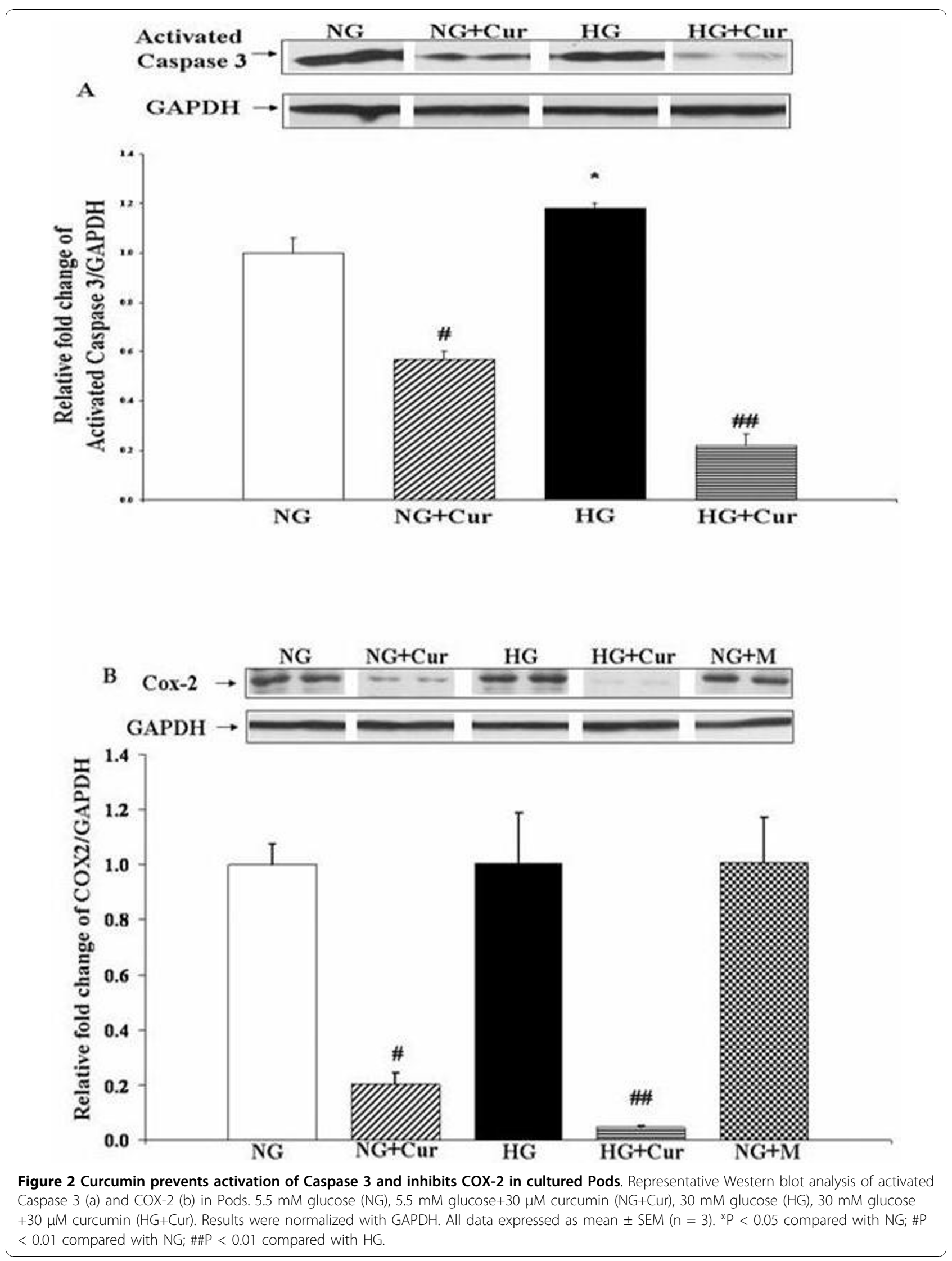


A

\begin{tabular}{|c|c|c|c|c|c|c|}
\hline & \multicolumn{3}{|c|}{ Control } & \multicolumn{3}{|c|}{ DM } \\
\hline & Cur0 & Cur 5000 & Cus 7500 & Cur0 & Cur 5000 & Cur7500 \\
\hline \multicolumn{7}{|l|}{ Exp1 } \\
\hline DM acsertainment, mg/dl & $85.3 \pm 7.8$ & $70.4 \pm 3.5$ & ND & $183.7 \pm 12.6$ & $187.8 \pm 18.6$ & ND \\
\hline \multicolumn{7}{|l|}{ Exp2 } \\
\hline DM acsertainment, mg/dl & $78.0 \pm 2.2$ & $83.0 \pm 2.8$ & $91.5 \pm 2.5$ & $138.4 \pm 3.3$ & $165.1 \pm 13.0 \dagger$ & $204.3 \pm 21.7 \dagger$ \\
\hline Steady state, $5-11 \mathrm{wks}, \mathrm{mg} / \mathrm{dl}$ & $84.4 \pm 3.9$ & $77.8 \pm 3.7$ & $80.8 \pm 2.1$ & $255.3 \pm 3.4$ & $278.5 \pm 18.3$ & $253.8 \pm 30.4$ \\
\hline
\end{tabular}

B
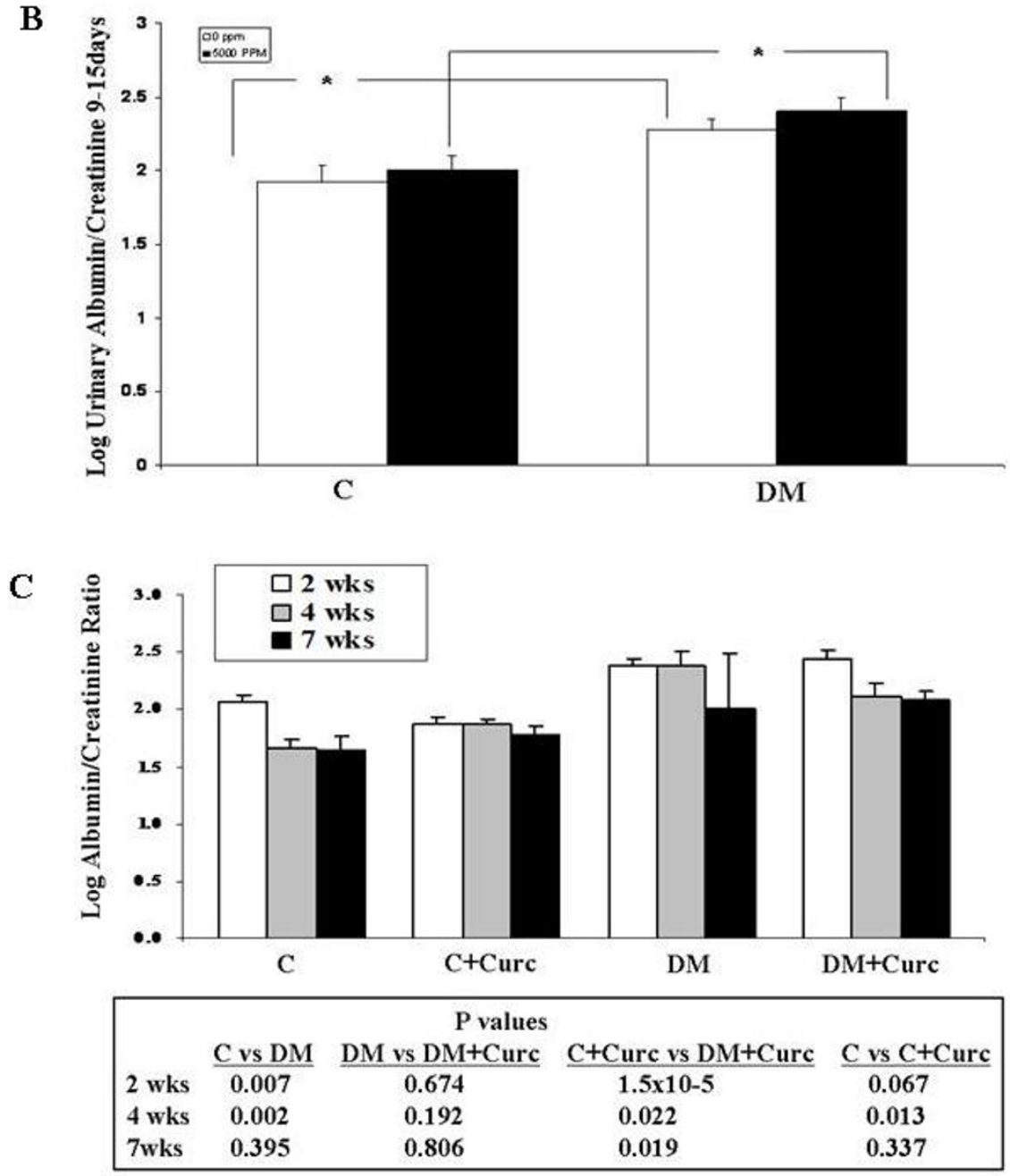

Figure 3 Fasting blood glucose values and effects of curcumin on DN measured by urinary albumin/creatinine in noDM and DM mice. (a) Fasting blood glucose in mice in Experiments 1 and 2. $24 \mathrm{~h}$ urine was collected to measure Ualb/cr in noDM and DM mice. (b) Ualb/cr from urine collected on days 9-15 for noDM and DM mice given control chow (0 ppm curcumin) or chow with 5,000 ppm curcumin. Mice were fed curcumin post-Stz injections (Experiment 1). (c) Ualb/cr at 2, 4 and 7 weeks for noDM and DM mice given control chow (0 ppm) or curcumin chow (data pooled for mice fed 5,000 and 7,500 ppm curcumin). Mice were fed curcumin pre-Stz injections (Experiment 2). All data are logtransformed $\left(\log _{10}\right)$. $* P<0.05$.

address the possibility that the failure to lower albuminuria in the DM mice was due to a dose effect, a $\mathrm{Cur}_{7,500}$ diet was also studied. Thus, Experiment 2 addressed three concerns with the design of Experiment 1: 1) that the administration of Cur began too late after diabetes induction; 2) that the dose of Cur was inadequate to induce a beneficial response; and 3) that the duration of therapy was too brief to demonstrate attenuation of severity even if it did not demonstrate attenuation of induction of diabetic nephropathy. Thus, 
in Experiment 2, mice received either $\mathrm{Cur}_{0}$ diets, or identical diets with $\mathrm{Cur}_{5,000}$ or $\mathrm{Cur}_{7,500}$. Diets were begun one week prior to $\mathrm{Stz}$ injections to achieve a steady state of Cur prior to the induction of DM. Then, DM was induced with five daily Stz injections. DM was confirmed one week after the last Stz injection. Fasting blood glucose one week after the last of the five Stz injections in the six groups are summarized (Figure 3a), and were higher in mice fed curcumin. For this reason, additional fasting blood glucose measurements were performed in these mice and in additional mice for up to 11 weeks after Stz-diabetes induction. These values failed to confirm this trend (Figure 3a). Overnight urines for Ualb/cr were collected in weeks 2, 4, and 7 (Figure 3c). Since no difference was apparent, data from mice who received $\mathrm{Cur}_{5,000}$ and $\mathrm{Cur}_{7,500}$ were pooled. The anticipated increment in Ualb/cr excretion in DM mice compared to noDM mice was observed, both at week 2 (noDM ${ }_{\text {Cur0 }}, 2.07 \pm 0.06 \mu \mathrm{g} / \mathrm{mg}$ vs. $\mathrm{DM}_{\mathrm{Cur} 0}, 2.38 \pm 0.07 \mu \mathrm{g} /$ $\mathrm{mg})$ and at week $4\left(\right.$ noDM $_{\mathrm{Cur} 0}, 1.65 \pm 0.09 \mu \mathrm{g} / \mathrm{mg}$ vs. $\left.\mathrm{DM}_{\text {Cur0 }}, 2.38 \pm 0.12 \mu \mathrm{g} / \mathrm{mg}\right)(\mathrm{P}<0.05)$. However, confirming the observations in Experiment 1, even when Cur feeding began before DM induction, Cur still failed to attenuate albuminuria in the DM animals.

\section{Urinary curcuminoid excretion as a measure of Cur pharmacodynamics}

Low bioavailability of Cur is thought to limit its potential clinical efficacy. Low plasma levels make these assays technically difficult to perform and relatively unreliable as a measure of curcumin's pharmacodynamic properties. Urinary HPLC curcuminoid measurements were therefore carried out to explore the potential use of a timed urine collection as a measure to reflect Cur pharmacodynamics. Total urine curcuminoid from a timed collection was measured in mice receiving $\mathrm{Cur}_{0}$ and $\mathrm{Cur}_{5,000}$ diets. Urine curcuminoid was expressed both as total urinary curcuminoid (Figure 4a) and also as urine cucuminoid adjusted for urine creatinine (Figure $4 \mathrm{~b}$ ). In urine samples with no Cur (eg, urine collected from mice receiving the $\mathrm{Cur}_{0}$ diet), an interfering substance was identified that resulted in a low level absorption value when HPLC measurements for Cur were made at $262 \mathrm{~nm}$. After adjusting for this at $262 \mathrm{~nm}$, there was no measurable curcuminoid in mice fed $\mathrm{Cur}_{0}$ diets. Urinary curcuminoid was abundantly detected in mice fed the $\operatorname{Cur}_{5,000}$ diet. The total urinary curcuminoid excretion in both noDM $\mathrm{Cur5,000}(3.08 \pm 1.09 \mathrm{nMol})$ and $\mathrm{DM}_{\mathrm{Cur} 5,000}(8.61 \pm 1.93 \mathrm{nMol})$ mice was easily measurable; the levels in DM and noDM mice given the $\mathrm{Cur}_{0}$ chow were generally undetectable. When adjusted for urine creatinine excretion, urinary Cur/cr levels were much higher in $\mathrm{DM}_{\mathrm{Cur} 5,000}(24.74 \pm 6.56 \mathrm{nmol} / \mathrm{mg})$ compared to noDM ${ }_{\text {Cur } 5,000}(5.30 \pm 0.85 \mathrm{nmol} / \mathrm{mg} ; \mathrm{P}<$
0.05) mice. This large difference can be accounted for by polyphagia and low muscle mass (and therefore low urine creatinine excretion) in the diabetic mice. $\mathrm{DM}_{\mathrm{Cur}}$ mice ingested somewhat more food than those with noDM ${ }_{\text {Curo }}(24.5 \pm 2.05$ vs. $19.8 \pm 1.03$ gm, $\mathrm{P}=0.10)$, although this difference did not reach statistical significance. $\mathrm{DM}_{\mathrm{Cur} 5,000}$ mice also ingested significantly more food than the noDM ${ }_{\mathrm{Cur} 5,000}$ group $(21.3 \pm 1.48 \mathrm{gm}$ vs. $16.4 \pm 0.93$ gm, $\mathrm{P}<0.05)$, but both $\mathrm{Cur}_{5,000}$ groups consumed less food than the $\mathrm{Cur}_{0}$ groups (Figure 5). Urine curcuminoid/cr excretion in DM mice was approximately four times higher than the noDM mice, but food intake was only $\sim 50 \%$ higher. Total urine creatinine over the 12-hour collection period in the diabetic mice was $261 \pm 72 \mu \mathrm{g}$, and in the non-diabetic control mice was $548 \pm 128 \mu \mathrm{g}$, reflecting the lower muscle mass in the more wasted diabetic animals. Taken together, the polyphagia and the reduced muscle mass of the diabetic mice accounted for the large observed differences in the urine curcuminoid/creatinine ratio in the DM compared to noDM mice. In addition, the data show incontrovertibly that renal exposure to curcuminoid was abundant. The data demonstrate that the failure to attenuate diabetic nephropathy in the DBA2J mice was not due to a failure of the administered Cur and/or its metabolites to reach the target organ. Furthermore, these results suggest that urinary curcuminoid/cr measurements may be a reliable measure of Cur bioavailability.

\section{Curcumin activated renal cortical p38MAPK and reduced total HSP25 in Stz-DM mice}

In renal cortical samples from mice with DM for 9-15 days, curcumin feeding induced a trend toward phosphorylation of p38MAPK $\left(\mathrm{DM}_{\mathrm{Cur} 0}, 1.0 \pm 0.09\right.$ vs. $\mathrm{DM}_{\mathrm{Cur} 5,000}, 2.0 \pm 0.39 ; \mathrm{P}=0.07$; Figure 6a) and significantly decreased total HSP25 10-fold (DM $\mathrm{Dur}_{\mathrm{Cu}}, 1.0 \pm$ 0.006 vs. $\mathrm{DM}_{\mathrm{Cur} 5,000}, 0.11 \pm 0.004 ; \mathrm{P}<0.01$; Figure $\left.6 \mathrm{~b}\right)$. These in vivo data, particularly those observed for HSP25, demonstrate the biological activity of curcumin in the kidney despite its failure to attenuate albuminuria.

\section{The effect of curcumin feeding on urinary 12-HETE/cr excretion in noDM and DM mice}

We measured urine 12-HETE/cr in samples collected on days 9 and 15 (Figure 7). Urinary 12-HETE/cr was higher in DM than in noDM animals receiving either $\operatorname{Cur}_{0}(\mathrm{P}<$ $0.01)$ or $\operatorname{Cur}_{5,000}$ chow $(\mathrm{P}=0.14)$. These results are consistent with the activation of the 12/15-lipoxygenase (12/15 LO) pathway in diabetes [28]. Diabetic mice fed $\mathrm{DM}_{\mathrm{Cur5,000}}$ had numerically higher urinary12-HETE/cr levels than $\mathrm{DM}_{\text {Cur } 0}$ mice $(4.27 \pm 0.14 \mathrm{ng} / \mathrm{mg}$ vs $3.87 \pm 0.10$ $\mathrm{ng} / \mathrm{mg})(\mathrm{P}<0.05)$. Moreover, even in noDM mice, curcu$\mathrm{min}$ in the diet increased urine 12-HETE/cr (noDMCur5,000, $3.92 \pm 0.13 \mathrm{ng} / \mathrm{mg}$ vs noDM ${ }_{\text {Cur0 }}$ diet, $3.30 \pm 0.12$ 

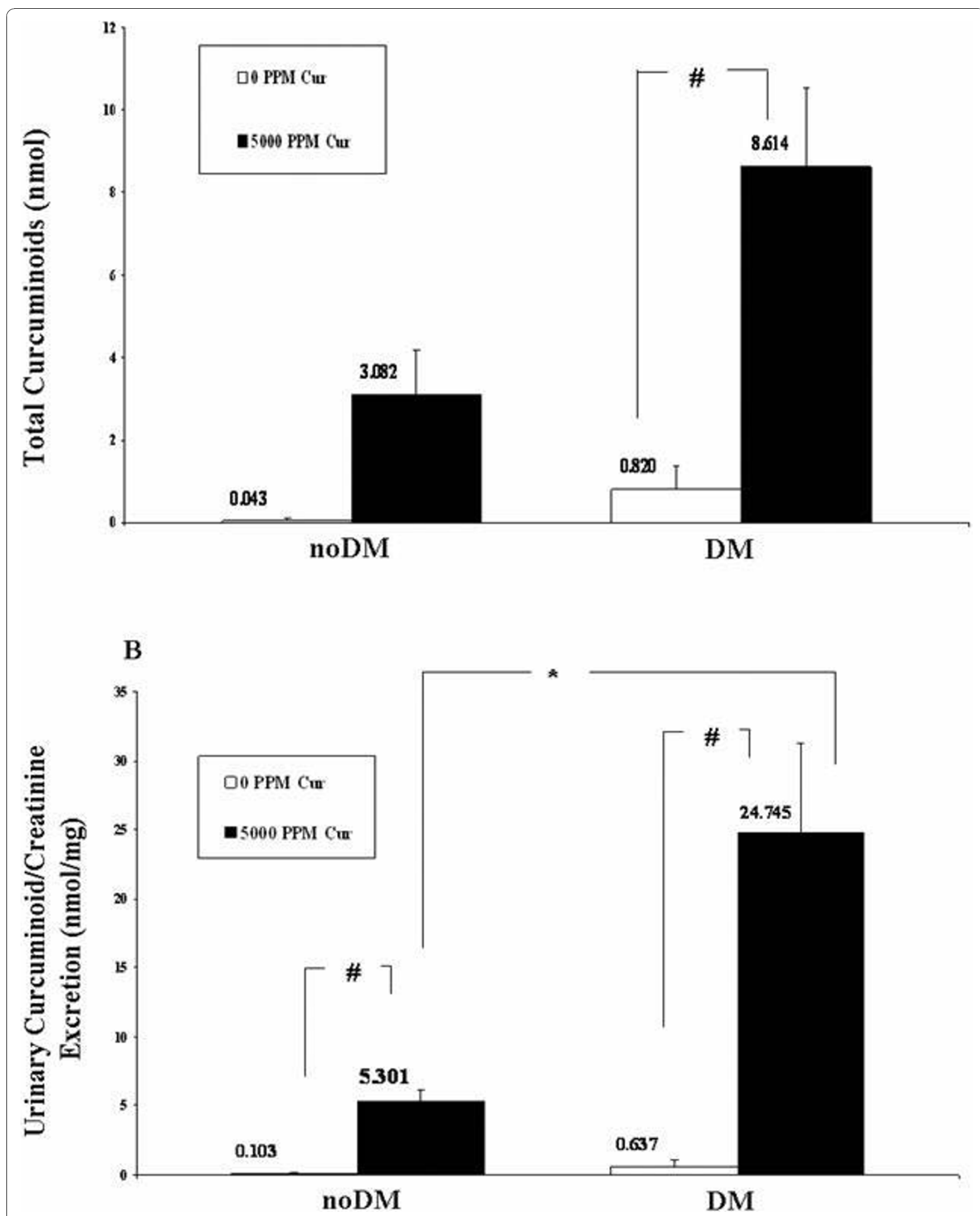

Figure 4 Urinary curcuminoid excretion in noDM and DM mice fed with curcumin versus control chow. Curcumin metabolites were measured by High Performance Liquid Chromatography (HPLC) as a measure of bioavailability in a timed urine collection. (a) Total urinary curcuminoids in $\mathrm{nmol}$ and (b) Urinary curcumin/creatinine in $\mathrm{nmol} / \mathrm{mg}$. All data are log-transformed $\left(\log _{10}\right)$. ${ }^{*} \mathrm{P}<0.05$; \#P $<0.01$. 


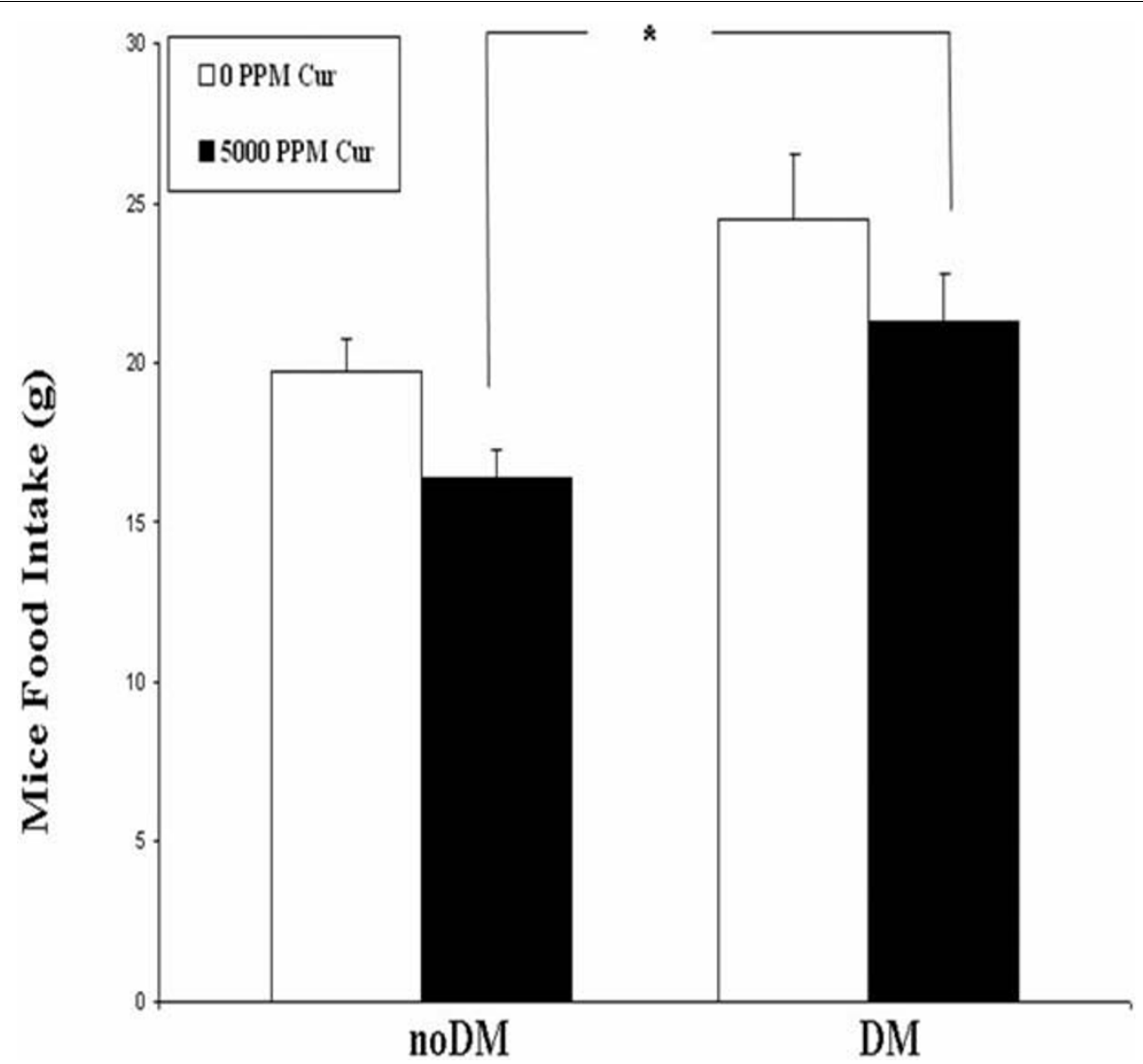

Figure 5 Mouse Food Intake. After Stz-injection and curcumin feeding began (Experiment 1), the total amount of control chow (0 ppm curcumin) or curcumin chow $\left(5,000 \mathrm{ppm}\right.$ curcumin) consumed by each mouse over the preceding 4 days was measured on day 4 . ${ }^{*} P<0.05$.

$\mathrm{ng} / \mathrm{mg}, \mathrm{P}<0.01)$. These results further confirm the pharmacodynamic HPLC data and show that curcumin induced a renal biological effect, a conclusion also consistent with the decrement in HSP25 during curcumin feeding.

\section{Conclusions}

Curcumin (diferuloylmethane) has anti-inflammatory, anti-oxidant, and anti-proliferative properties. It inhibits the arachidonic acid pathway, especially COX-2 [29-33]. It has been reported to maintain cytoskeletal stress fibers in cells exposed to stressors [34], and in some settings, it is cytoprotective [19,35-38]. However, in high concentrations, it is also pro-apoptotic [39]. The latter property has been exploited extensively in vitro and in vivo, and curcumin has been utilized experimentally as a potential therapy in cancer [40-46].

The in vitro studies reported herein are consistent with some, but not all of these observations. Our experiments show that in podocytes cultured under basal or high glucose conditions, acute exposure to curcumin induced the phosphorylation of both p38MAPK and downstream HSP25. These changes were associated with inhibition of COX-2, and a trend towards attenuation of F- to G-actin cleavage. In association with these changes, a dramatic inhibition of activated caspase- 3 was observed. The pro-survival, anti-inflammatory, antiapoptotic, and structural preservation tendencies induced by curcumin in podocytes in vitro could be potentially therapeutic if replicated in vivo. Therefore, we tested whether curcumin would diminish the albuminuria characteristic of DN in experimental animals. We measured curcumin and its metabolites in timed urine collections to verify renal curcuminoid exposure. Our findings are distinct from other publications in which benefits for DN conferred by curcumin are reported [47-50]. Curcumin administered in the diet either before or 1 week after Stz-DM in DBA2J mice failed to ameliorate albuminuria. A trend towards renal cortical p38MAPK activation was observed $(p=0.07$ ), and total HSP25 content diminished dramatically, the latter confirming that curcumin did induce a biological effect in the kidneys. Furthermore, the anticipated decrement in 12/15-LO activation did not materialize, and urinary 12-HETE was increased in curcumin-fed diabetic mice. The decrement in total HSP25 and the 

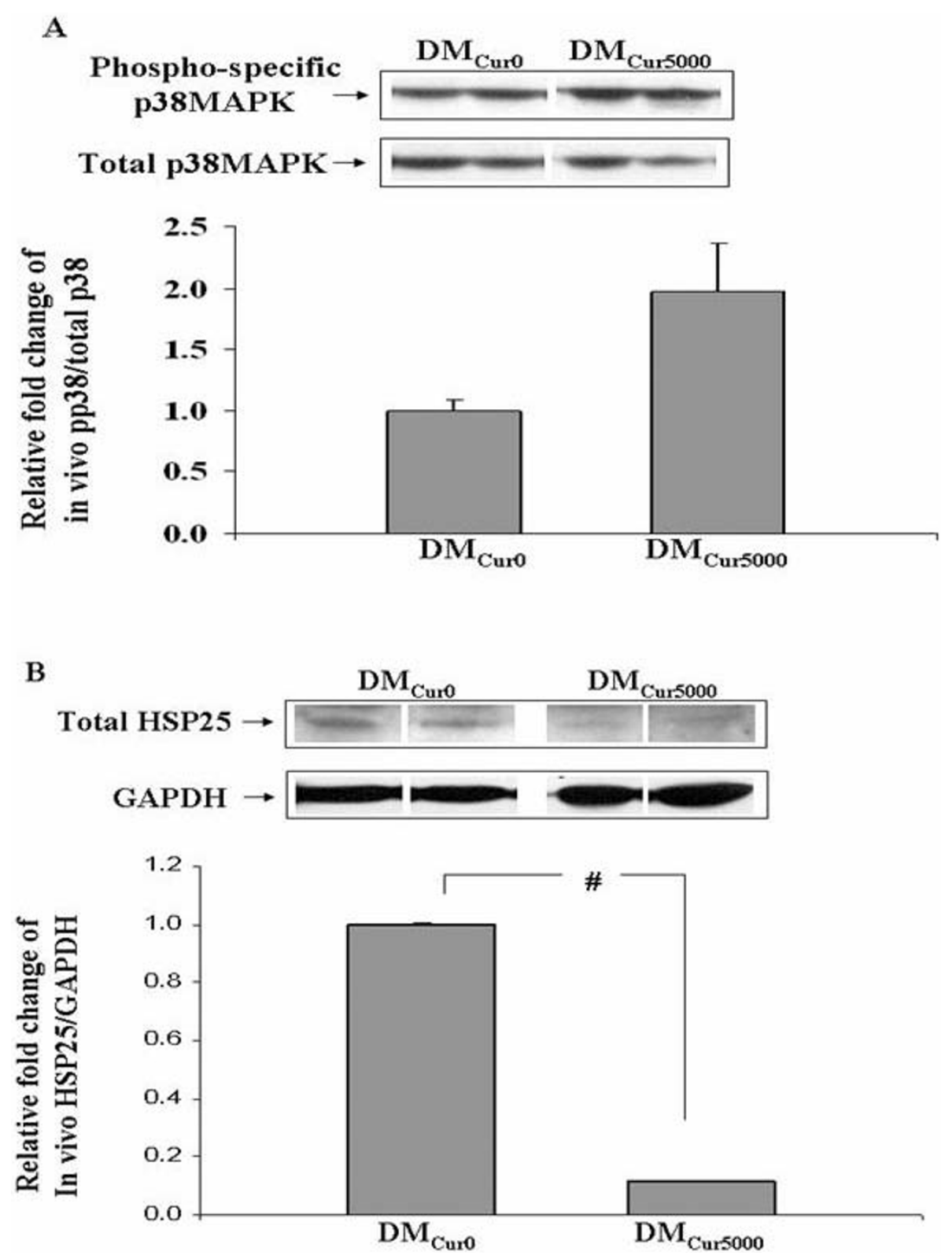

Figure 6 Effects of Curcumin on P38MAPK and total HSP25 on Stz-DM mice. Representative Western blot and quantitative evaluation of phospho-specific P38MAPK (a) and total HSP25 relative to GAPDH (b) in renal cortex of DM Curo and DM $M_{\text {Curs,000 }}$ mice. ${ }^{* P}<0.05$; \#P $<0.01$.

increase in urine 12-HETE excretion in curcumin-fed DBA2J mice may be markers and/or mediators, at least in part, of the failure of curcumin to achieve an antialbuminuric effect in these diabetic mice.

In our in vitro studies, the most surprising result was the attenuation of the apoptosis marker, activated caspase-3, along with an increase in phosphorylation of p38MAPK in curcumin-treated podocytes. Activation of p38MAPK has been shown to induce apoptosis predominantly in cultured neoplastic cells [44,45,51-58], but also in non-neoplastic cells [59-63]. However, p38MAPK activation is not always pro-apoptotic in experimental settings, and it is cytoprotective in some cells and circumstances. For instance, in human colonic carcinoma cells, inhibition of p38MAPK activity with SB203580 increased drug-induced apoptosis [64]. In addition, in a model of anoxia-reoxygenation-induced lung endothelial cell apoptosis, SB203580 or transfection with a p38 $\alpha$ dominant negative mutant each inhibited the anti-apoptotic effects of carbon monoxide through a pathway involving the modulation of caspase 3 [65]. Thus, the relationship between p38MAPK activation and apoptosis 


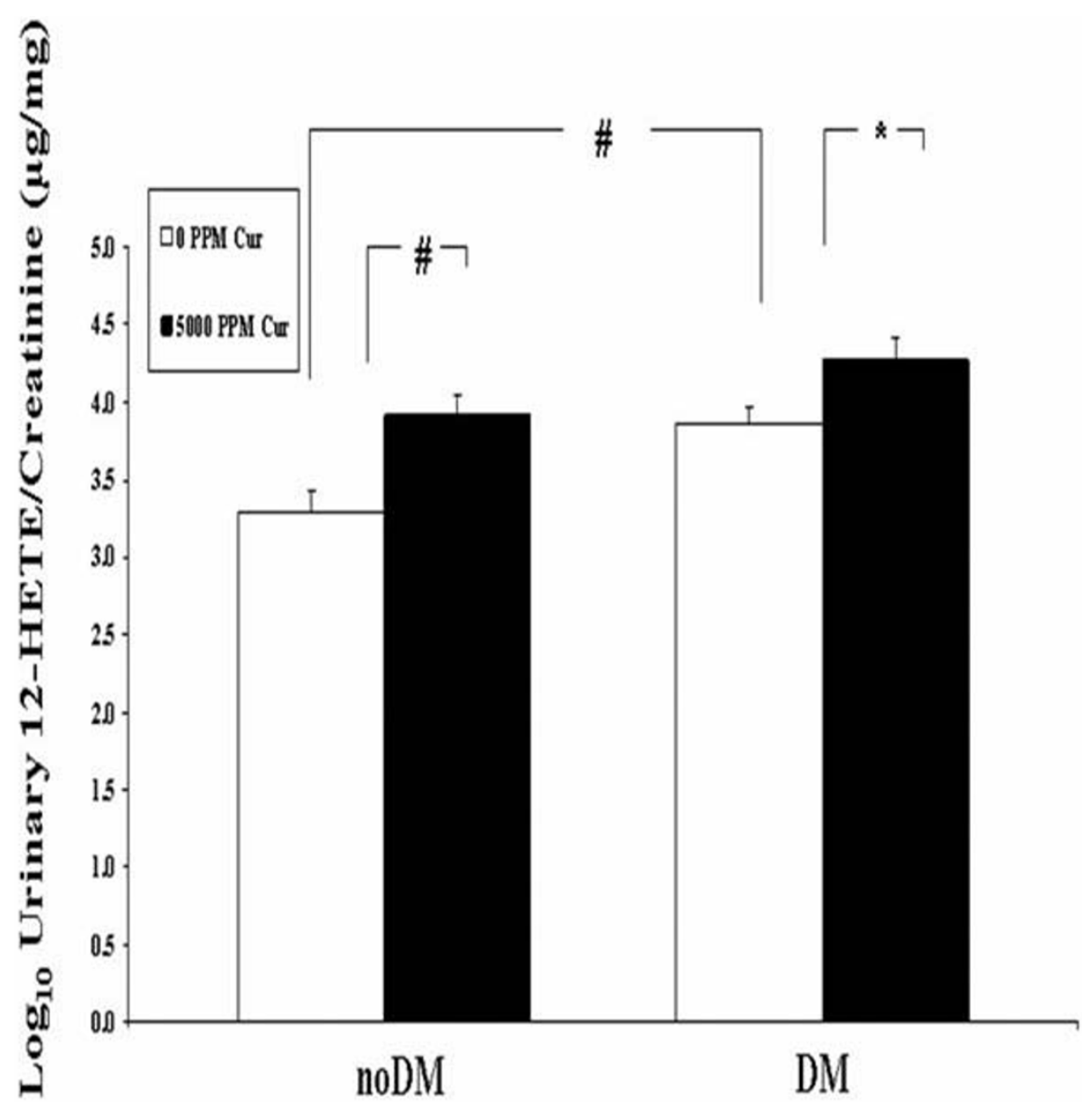

Figure 7 Curcumin did not lower $\mathrm{U}$ 12-HETE/cr excretion in noDM and DM mice. Urinary 12-HETE/cr ratios for noDM and DM mice fed chow with 0 and 5,000 ppm curcumin. Mice were fed curcumin post-Stz injections (Experiment 1). Graph represents pooled data (day 9 and 15). ${ }^{*} \mathrm{P}<0.05 ;$ \#P $<0.01$.

may be dependent on cell type and the inciting stimulus, and both apoptosis and cytoprotection have been observed $[38,57,64,65]$. Our in vitro data suggest that in curcumin-stimulated podocytes under the conditions of study, the p38MAPK-HSP25-apoptosis axis favored cytoprotection, consistent with a minority of published reports in the literature. Since phosphorylated p38MAPK is one of the major regulators of the phosphorylation of downstream HSP25, activation of the p38MAPK-HSP25 pathway may explain both the tendency towards maintenance of the actin cytoskeleton and the attenuation of apoptosis in this in vitro model.

HSPs are a pleiotropic family of chaperone proteins with numerous functions. Phosphorylated HSP25 monomers play a role in the maintenance of the actin cytoskeleton during cell stress [11,13,66-69]. One group recently reported that the anti-apoptotic properties of HSP25/27 were ascribable to its maintenance of actin cytoskeletal integrity, which prevented mitochondria from releasing cytochrome c [70]. Actin cytoskeletal disruption may be both a marker and a mechanism of apoptosis [71-73]. Through the stabilization of actin, phosphorylated HSP25 may attenuate apoptosis. The anti-apoptotic activities of phosphorylated HSP25/27 in cells exposed to TNF $\alpha$ have also been ascribed to enhanced IKK $\gamma$ proteasomal degradation, which increases NF $\kappa \mathrm{B}$ activity in some cells [74-76], but not in others [77]. Non-phosphorylated HSP25 oligomers also enhance cell survival, but through mechanisms involving the inhibition of canonical targets in the mitochondrial and death-domain apoptotic pathways and through inhibition of NF $\kappa \mathrm{B}$ activation [74-81]. While curcumin increases HSP70 [19-22], limited information is available concerning the effect of curcumin on HSP25/27. Curcumin increased total HSP27 in glioma cells cultured under stress-conditions by prolonging the stress-induced activation of the heat shock element-binding activity of heat shock transcription factor [82]. In in vivo studies, 
these same investigators also showed further induction of HSP 25 by curcumin in the adrenal glands and livers of rats exposed to heat stress. In contrast, in our in vitro studies in curcumin-treated podocytes, phosphorylated HSP25 was increased, but not total HSP25 (not shown). Since phosphorylated HSP25 regulates the maintenance of the actin cytoskeleton and $\mathrm{NF} \kappa \mathrm{B}$ activation, our in vitro data are consistent with a role for activation of the p38MAPK-HSP25 pathway in the observed trend favoring maintenance of stress fibers in curcumin-treated podocytes during high glucose exposure. In other published experiments consistent with these findings, curcumin has been reported to increase stress fibers and Factin in prostate cancer cells [34]. Thus, the increase in phosphorylated HSP25 induced by curcumin in vitro may contribute to the observed curcumin-associated trend to maintain actin stress fibers and the decrement in activated caspase- 3 .

Finally, curcumin inhibited COX-2 in vitro. Curcumin is well-known to inhibit the arachidonic acid pathway, particularly COX-2 [30-33,83-86]. Our in vitro results showing inhibition of COX-2 by curcumin is consistent with these other published studies. Medicinal COX-2 inhibitors such as celecoxib induce apoptosis, but COX2 inhibition by other means, including molecular interventions, do not necessarily induce apoptosis [87]. Taken together, our in vitro data demonstrate that in podocytes cultured in normal or high glucose media, curcumin activates the p38MAPK-HSP25 pathway, inhibits COX-2, attenuates apoptosis, and likely contributes towards the trend for cytoskeletal maintenance.

In contrast to our findings in vitro, which corroborate other published findings, our inability to demonstrate a benefit for curcumin in diabetic nephropathy (DN) in DBA2J mice is unique among published studies in this field. We were unable to show an anti-albuminuric effect or an attenuation in urine 12-HETE excretion in diabetic DBA2J mice, despite our clear ability to demonstrate renal exposure to curcuminoids by measuring curcumin and its metabolites in urine. Curcumin has previously been reported to inhibit proteinuria, albuminuria, and/or histologic change in Stz-DN in rats [48-50]. Species, strain, and/or dosing differences may underlie our inability to demonstrate a clinical benefit from curcumin in mice while others reported benefit in rats. Indeed, in a recently published paper, Li et al [88] showed that in the DBA2J mouse used herein, which has a naturally occurring mutation in the gene glycoprotein non-metastatic melanoma protein $\mathrm{b}$ (gpnmb), there is a defect in renal reparative processes. It is possible that the negative results observed for curcumin in this mouse are due to this inherited reparative defect. It is well-known that both susceptibility to disease and responsiveness to therapy are influenced by genetic predisposition." However, review of the publications in which benefit from curcumin was actually reported raises some skepticism concerning the robustness of these observations. In the work by Babu et al in Stz-DN in Wistar rats, renal hypertrophy, measures of tubular proteinuria, urine excretion of proteins with $\mathrm{MW}>66 \mathrm{kD}$, and histological change were improved at 8 weeks [49]. Of note, the investigators went to great lengths to publish the results of a large number of tubular and large molecular weight proteinuria markers, but did not publish their albuminuria result. In addition, blood glucose data are not provided, a description of how the histologic analyses were performed is lacking, and the photomicrographs provided are of very low magnification and not easily interpretable by the reader. In the work by Sharma et al [48], a claim for the benefit of curcumin on DN was based on lower albuminuria concentration (but not lower urine albumin/creatinine ratio or albumin/unit time, which are the standard methods of reporting); lower serum creatinine and urea nitrogen; higher creatinine clearance; and less renal pathology in the curcumin-treated diabetic rats compared to diabetic rats on a control diet. Unfortunately, in this experiment, the curcumin-treated rats had lower plasma glucose levels than the diabetic rats receiving a control diet. The authors attribute this to the curcumin treatment itself. Nevertheless, the difference in glycemic control confounds the interpretation of the role of curcumin in directly ameliorating DN in this experiment. Furthermore, the time point of study ( 6 weeks after diabetes induction) was shorter than optimal for the establishment of DN in rats, and the histologic sections provided are of inadequate quality, falling short of establishing DN changes. In the work by Chiu et al [47], Sprague-Dawley rats with Stz-DN were studied after 4 weeks. Curcumin-treated rats had improvement in a number of biochemical parameters including attenuation of renal mRNAs for fibronectin, eNOS, TGF-beta, heme oxygenase-1, and improvements in glomerular nitrotyrosine, 8-OHdG, transcription coactivator $\mathrm{p} 300$, and $\mathrm{NF} \kappa \mathrm{B}$. Albuminuria was not measured, the studies were not carried out beyond 4 weeks, and, as pointed out by others [89], key controls for the ethanol and DMSO diluents were lacking. In the work by Tikoo et al [50], Stz-DN was studied in Sprague-Dawley rats after 8 weeks, having received curcumin treatment for 6 weeks. Improvement in $\mathrm{DN}$ was inferred from modulation in the curcumin-treated group of blood urea nitrogen, serum creatinine, and kidney/body weight ratio. Acceptance of this conclusion is limited by concerns regarding the use of BUN and serum creatinine in polyuric animals with low muscle mass as robust measures of renal function, the methodology used for the measure of serum creatinine (picric acid, [90]), and the absence of a measure of albuminuria. Taken together, no prior report showing a beneficial effect of curcumin on Stz-DN actually measured the urine albumin/creatinine ratio, a cardinal manifestation of $\mathrm{DN}$, 
and many of the studies had other significant design flaws. The work reported herein is the only one to date to demonstrate pharmacodynamic data consistent with renal exposure to curcumin and its metabolites, biochemical changes consistent with a renal biological effect of curcumin, but no ameliorative effect on albuminuria, which is the key clinical feature of early DN.

The burden of explaining why curcumin failed to ameliorate albuminuria in these mice remains, and one can only speculate. A unique response in this mouse strain cannot be ruled out, as it is well-appreciated that genetic backgrounds influence both disease susceptibility and response to treatments. In addition, at least in Experiment 2, fasting blood glucose was higher at week 1 in mice receiving curcumin, a finding that was not replicated in measures taken at later weeks. These early differences were statistically significant, but their biological significance is uncertain. Nevertheless, we cannot exclude that this apparently transient and relatively small increment in blood glucose early in disease development contributed to the lack of apparent efficacy of curcumin to attenuate albuminuria. However, some biological observations may be relevant. We have previously shown in podocytes cultured under normal or high glucose conditions, and in renal cortical tissue from diabetic and control rats, that phosphorylated HSP25 appears as an acute adaptation to glycemic stress. This adaptation was associated with maintenance of the podocyte cytoskeleton in vitro, and an association with normoalbuminuria in vivo. Decrements in phosphoHSP25 later in the course of Stz-DN were associated with the appearance of albuminuria and glomerular podocyte effacement [18]. We have also reported that in mice overexpressing HSP27, there was diminished beta cell apoptotic death from Stz and an attenuation of StzDN. In other studies in vitro, direct binding of HSP25/ 27 to the upstream regulator of $\mathrm{NF} \kappa \mathrm{B}$, IKK $\gamma$ (NEMO), inhibited pancreatic beta cell apoptosis [74-77]. These data underscore the significant relationship between phosphorylated and non-phosphorylated HSP25/27 with cytoskeletal maintenance and cytoprotection from apoptotic death. Taken together, the experimental results published herein are consistent with the hypothesis that the profound decrease in total HSP25 in the curcumintreated Stz-DN mice may confer a susceptibility to loss of structural cellular integrity and apoptosis of cells comprising the glomerular capillary wall, resulting in albuminuria. In Tikoo et al, a decrement in renal HSP25 is also reported in Stz-DN rats fed with curcumin [50].

Finally, the failure to mitigate albuminuria in the curcumin-treated Stz-DN mice may have been related to the persistent activity of the arachidonic acid pathway enzyme, 12/15-LO. Natarajan et al showed that the 12/ 15-LO pathway mediates the actions of the key effector molecules that induce albuminuria and extracellular matrix accumulation in DN, including glucose, TGFbeta, angiotensin II, and PDGF in vascular smooth muscle cells [91]. Our prior work showed that 12/15-LO mRNA and protein are induced in mesangial cells in HG and in Stz-DN rat glomeruli [6,92-94]. In podocytes in vitro and in Stz-DN, HG stimulated 12/15-LO mRNA and protein synthesis, podocyte $\mathrm{p} 38 \mathrm{MAPK}$ activation, and collagen $\alpha$ (IV) mRNA and protein, while 12/15-LO inhibition diminished HG-stimulated podocyte collagen $\alpha$ (IV) mRNA and protein [6].

Curcumin has been reported to inhibit lipoxygenases by one group of investigators [95], but was found to be a substrate of lipoxygenases by another group [96]. Urine 12-HETE is a reliable measure of activation of the 12/15-LO pathway in vivo [97], and in these curcumintreated mice, the urine 12-HETE/cr ratio was increased. In prior studies performed to inhibit 12/15-LO in StzDN rats, our published work showed that chemical inhibition of $12 / 15$ - LO is only transiently effective, and that tachyphylaxis occurs rapdily [98]. In the rats receiving the chemical inhibitor, a linear relationship between urine 12-HETE excretion and albuminuria was observed [97]. The failure of curcumin to suppress activation of $12 / 15-\mathrm{LO}$, as evidenced by the high urine 12 -HETE/cr ratio, may have contributed to the albuminuria observed in the curcumin-treated diabetic DBA2J mice.

Thus, our data extend and confirm prior in vitro evidence concerning the effects of curcumin on cultured cells exposed to glycemic stress. In cultured podocytes, curcumin induced the phosphorylation of p38MAPK and downstream HSP25, inhibited COX-2 and the activation of caspase-3, and demonstrated a tendency to attenuate $\mathrm{F}$-actin cleavage to G-actin monomers. However, in DBA2J mice with Stz-DM, despite pharmacodynamic proof of exposure to orally administered curcumin by timed urine collections measuring excreted curcuminoids, curcumin attenuated the HSP25 response to Stz-DM, increased urinary 12-HETE excretion, and failed to attenuate the albuminuria of DN. While strain, species, and dosing issues may be responsible for this negative result, the biological responses of HSP25 and $12 / 15$-LO to curcumin may underlie this failure. Thus, despite encouraging in vitro effects, these data do not confirm prior published in vivo work and suggest that curcumin is not universally useful in ameliorating DN. In addition, these studies suggest that timed urine collections may be useful for monitoring curcumin dosing and renal pharmacodynamics.

\section{Acknowledgements}

This work was supported by grant AT002945 from the National Center for Complementary and Alternative Medicine. Ms Phillips was additionaly funded by the National Center for Complementary and Alternative Medicine 
through PA-05-015, Research supplements to promote diversity in healthrelated research. The authors thank Vladimir Badmaev, MD, PhD, VP Medical \& Scientific Affairs of the Sabinsa Corporation for the provision of curcumin.

\section{Authors' contributions}

JM and LP carried out the molecular studies, animal experiments, data analysis and drafted the manuscript. YW carried out molecular studies and performed data analysis in the revision manuscript. TD and RN participated in the design of the study. JL participated in animal experiments. SA conceived of the study, and participated in its design and coordination and wrote the manuscript. All authors read and approved the final manuscript.

\section{Competing interests}

The authors declare that they have no competing interests.

Received: 10 July 2010 Accepted: 12 November 2010 Published: 12 November 2010

\section{References}

1. Schieppati A, Remuzzi G: Proteinuria and its consequences in renal disease. Acta Paediatr Suppl 2003, 92(443):9-13.

2. Hall A: G proteins and small GTPases: distant relatives keep in touch. Science 1998, 280(5372):2074-5

3. Raman N, Atkinson SJ: Rho controls actin cytoskeletal assembly in renal epithelial cells during ATP depletion and recovery. Am J Physiol 1999, 276(6 Pt 1):C1312-24.

4. Coso OA, Chiariello M, Yu JC, Teramoto H, Crespo P, Xu N, et al: The small GTP-binding proteins Rac1 and Cdc42 regulate the activity of the JNK/ SAPK signaling pathway. Cell 1995, 81(7):1137-46.

5. Minden A, Lin A, Claret FX, Abo A, Karin M: Selective activation of the JNK signaling cascade and c-Jun transcriptional activity by the small GTPases Rac and Cdc42Hs. Cell 1995, 81(7):1147-57.

6. Kang SW, Natarajan R, Shahed A, Nast CC, LaPage J, Mundel P, et al: Role of 12-lipoxygenase in the stimulation of p38 mitogen-activated protein kinase and collagen alpha5(IV) in experimental diabetic nephropathy and in glucose-stimulated podocytes. J Am Soc Nephrol 2003, 14(12):3178-87.

7. Dunlop ME, Muggli EE: Small heat shock protein alteration provides a mechanism to reduce mesangial cell contractility in diabetes and oxidative stress. Kidney Int 2000, 57(2):464-75.

8. Isermann B, Vinnikov IA, Madhusudhan T, Herzog S, Kashif M, Blautzik J, et al: Activated protein $C$ protects against diabetic nephropathy by inhibiting endothelial and podocyte apoptosis. Nat Med 2007, 13(11):1349-58.

9. Didelot C, Schmitt E, Brunet M, Maingret L, Parcellier A, Garrido C: Heat shock proteins: endogenous modulators of apoptotic cell death. Handb Exp Pharmacol 2006, , 172: 171-98.

10. Macario AJ, Conway de Macario E: Stress and molecular chaperones in disease. Int J Clin Lab Res 2000, 30(2):49-66.

11. Guay J, Lambert H, Gingras-Breton G, Lavoie JN, Huot J, Landry J: Regulation of actin filament dynamics by p38 map kinase-mediated phosphorylation of heat shock protein 27. J Cell Sci 1997, 110(Pt 3):357-68.

12. Loktionova SAaKAE: Phosphatase inhibitors prevent HSP27 dephosphorylation, destruction of stress fibrils, and morphological changes in endothelial cells during ATP depletion. Bull Exp Biol Med 2001, 132:914-917.

13. Kubisch C, Dimagno MJ, Tietz AB, Welsh MJ, Ernst SA, Brandt-Nedelev B, et al: Overexpression of heat shock protein $\mathrm{Hsp27}$ protects against cerulein-induced pancreatitis. Gastroenterology 2004, 127(1):275-86.

14. Okamoto CT: HSP27 and signaling to the actin cytoskeleton focus on "HSP27 expression regulates CCK-induced changes of the actin cytoskeleton in CHO-CCK-A cells". Am J Physiol 1999, $277(6$ Pt 1):C1029-31.

15. Pichon S, Bryckaert M, Berrou E: Control of actin dynamics by p38 MAP kinase - Hsp27 distribution in the lamellipodium of smooth muscle cells. J Cell Sci 2004, 117(Pt 12):2569-77.

16. Smoyer WE, Ransom RF: Hsp27 regulates podocyte cytoskeletal changes in an in vitro model of podocyte process retraction. Faseb J 2002, 16(3):315-26.

17. Van Why SK, Mann AS, Ardito T, Thulin G, Ferris S, Macleod MA, et al: Hsp27 associates with actin and limits injury in energy depleted renal epithelia. J Am Soc Nephrol 2003, 14(1):98-106.
18. Dai T, Natarajan R, Nast CC, LaPage J, Chuang P, Sim J, et al: Glucose and diabetes: effects on podocyte and glomerular p38MAPK heat shock protein 25, and actin cytoskeleton. Kidney Int 2006, 69(5):806-14.

19. Sood A, Mathew R, Trachtman H: Cytoprotective effect of curcumin in human proximal tubule epithelial cells exposed to shiga toxin. Biochem Biophys Res Commun 2001, 283(1):36-41.

20. Chen YC, Kuo TC, Lin-Shiau SY, Lin JK: Induction of HSP70 gene expression by modulation of $\mathrm{Ca}(+2)$ ion and cellular $\mathrm{p} 53$ protein by curcumin in colorectal carcinoma cells. Mol Carcinog 1996, 17(4):224-34.

21. Dunsmore KE, Chen PG, Wong HR: Curcumin, a medicinal herbal compound capable of inducing the heat shock response. Crit Care Med 2001, 29(11):2199-204.

22. Chen YC, Tsai SH, Shen SC, Lin JK, Lee WR: Alternative activation of extracellular signal-regulated protein kinases in curcumin and arseniteinduced HSP70 gene expression in human colorectal carcinoma cells. Eur J Cell Biol 2001, 80(3):213-21.

23. Mundel P, Reiser J, Zuniga Mejia Borja A, Pavenstadt H, Davidson GR, Kriz W, et al: Rearrangements of the cytoskeleton and cell contacts induce process formation during differentiation of conditionally immortalized mouse podocyte cell lines. Exp Cell Res 1997, 236(1):248-58

24. Blikstad I, Markey F, Carlsson L, Persson T, Lindberg U: Selective assay of monomeric and filamentous actin in cell extracts, using inhibition of deoxyribonuclease I. Cell 1978, 15(3):935-43.

25. Papakonstanti EA, Emmanouel DS, Gravanis A, Stournaras C: Na+/Pi cotransport alters rapidly cytoskeletal protein polymerization dynamics in opossum kidney cells. Biochem J 1996, 315(Pt 1):241-7.

26. Lim GP, Chu T, Yang F, Beech W, Frautschy SA, Cole GM: The curry spice curcumin reduces oxidative damage and amyloid pathology in an Alzheimer transgenic mouse. J Neurosci 2001, 21(21):8370-7.

27. Heath DD, Pruitt MA, Brenner DE, Rock CL: Curcumin in plasma and urine: quantitation by high-performance liquid chromatography. J Chromatogr B Analyt Technol Biomed Life Sci 2003, 783(1):287-95.

28. Antonipillai I, Nadler J, Vu EJ, Bughi S, Natarajan R, Horton R: A 12lipoxygenase product, 12-hydroxyeicosatetraenoic acid, is increased in diabetics with incipient and early renal disease. J Clin Endocrinol Metab 1996, 81(5):1940-5.

29. Cho JW, Park K, Kweon GR, Jang BC, Baek WK, Suh MH, et al: Curcumin inhibits the expression of COX-2 in UVB-irradiated human keratinocytes ( $\mathrm{HaCaT}$ ) by inhibiting activation of AP-1: p38 MAP kinase and JNK as potential upstream targets. Exp Mol Med 2005, 37(3):186-92.

30. Chun KS, Keum YS, Han SS, Song YS, Kim SH, Surh YJ: Curcumin inhibits phorbol ester-induced expression of cyclooxygenase-2 in mouse skin through suppression of extracellular signal-regulated kinase activity and NF-kappaB activation. Carcinogenesis 2003, 24(9):1515-24.

31. Goel A, Boland CR, Chauhan DP: Specific inhibition of cyclooxygenase-2 (COX-2) expression by dietary curcumin in HT-29 human colon cancer cells. Cancer Lett 2001, 172(2):111-8.

32. Kang G, Kong PJ, Yuh YJ, Lim SY, Yim SV, Chun W, et al: Curcumin suppresses lipopolysaccharide-induced cyclooxygenase-2 expression by inhibiting activator protein 1 and nuclear factor kappab bindings in BV2 microglial cells. J Pharmacol Sci 2004, 94(3):325-8.

33. Zhang F, Altorki NK, Mestre JR, Subbaramaiah K, Dannenberg AJ: Curcumin inhibits cyclooxygenase-2 transcription in bile acid- and phorbol estertreated human gastrointestinal epithelial cells. Carcinogenesis 1999, 20(3):445-51.

34. Holy J: Curcumin inhibits cell motility and alters microfilament organization and function in prostate cancer cells. Cell Motil Cytoskeleton 2004, 58(4):253-68.

35. Hsuuw YD, Chang CK, Chan WH, Yu JS: Curcumin prevents methylglyoxalinduced oxidative stress and apoptosis in mouse embryonic stem cells and blastocysts. J Cell Physiol 2005, 205(3):379-86.

36. Zhu YG, Chen XC, Chen ZZ, Zeng YQ, Shi GB, Su YH, et al: Curcumin protects mitochondria from oxidative damage and attenuates apoptosis in cortical neurons. Acta Pharmacol Sin 2004, 25(12):1606-12.

37. Chan WH, Wu HJ, Hsuuw YD: Curcumin inhibits ROS formation and apoptosis in methylglyoxal-treated human hepatoma G2 cells. Ann N Y Acad Sci 2005, 1042:372-8.

38. Reuter S, Eifes S, Dicato M, Aggarwal BB, Diederich M: Modulation of antiapoptotic and survival pathways by curcumin as a strategy to induce apoptosis in cancer cells. Biochem Pharmacol 2008, 76(11):1340-51. 
39. Woo JH, Kim YH, Choi YJ, Kim DG, Lee KS, Bae JH, et al: Molecular mechanisms of curcumin-induced cytotoxicity: induction of apoptosis through generation of reactive oxygen species, down-regulation of $\mathrm{BCl}$ $\mathrm{XL}$ and IAP the release of cytochrome $\mathrm{c}$ and inhibition of Akt. Carcinogenesis 2003, 24(7):1199-208.

40. Singh M, Pandey A, Karikari CA, Singh G, Rakheja D: Cell cycle inhibition and apoptosis induced by curcumin in Ewing sarcoma cell line SK-NEP1. Med Oncol 2009.

41. Karunagaran D, Rashmi R, Kumar TR: Induction of apoptosis by curcumin and its implications for cancer therapy. Curr Cancer Drug Targets 2005, 5(2):117-29.

42. Lee HE, Berkowitz P, Jolly PS, Diaz LA, Chua MP, Rubenstein DS: Biphasic activation of p38MAPK suggests that apoptosis is a downstream event in pemphigus acantholysis. J Biol Chem 2009, 284(18):12524-32.

43. Hartojo W, Silvers AL, Thomas DG, Seder CW, Lin L, Rao H, et al: Curcumin promotes apoptosis, increases chemosensitivity, and inhibits nuclear factor kappaB in esophageal adenocarcinoma. Transl Oncol 2010, 3(2):99-108.

44. Watson JL, Hill R, Lee PW, Giacomantonio CA, Hoskin DW: Curcumin induces apoptosis in HCT-116 human colon cancer cells in a p21independent manner. Exp Mol Pathol 2008, 84(3):230-3.

45. Watson JL, Hill R, Yaffe PB, Greenshields A, Walsh M, Lee PW, et al: Curcumin causes superoxide anion production and p53-independent apoptosis in human colon cancer cells. Cancer Lett 2010.

46. Bill MA, Fuchs JR, Li C, Yui J, Bakan C, Benson DM Jr, et al: The small molecule curcumin analog FLLL32 induces apoptosis in melanoma cells via STAT3 inhibition and retains the cellular response to cytokines with anti-tumor activity. Mol Cancer 2010, 9(1):165.

47. Chiu J, Khan ZA, Farhangkhoee $H$, Chakrabarti S: Curcumin prevents diabetes-associated abnormalities in the kidneys by inhibiting p300 and nuclear factor-kappaB. Nutrition 2009, 25(9):964-72.

48. Sharma S, Kulkarni SK, Chopra K: Curcumin, the active principle of turmeric (Curcuma longa), ameliorates diabetic nephropathy in rats. Clin Exp Pharmacol Physiol 2006, 33(10):940-5.

49. Babu PS, Srinivassan K: Amelioration of renal lesions associated with diabetes by dietary curcumin in streptozotocin diabetic rats. Molec Cell Biochem 1998, 181:87-96.

50. Tikoo K, Meena RL, Kabra DG, Gaikwad AB: Change in post-translational modifications of histone $\mathrm{H} 3$, heat-shock protein-27 and MAP kinase p38 expression by curcumin in streptozotocin-induced type I diabetic nephropathy. Br J Pharmacol 2008, 153(6):1225-31.

51. Chen $Q$, Wang $Y, X u K, L u ~ G$, Ying Z, Wu L, et al: Curcumin induces apoptosis in human lung adenocarcinoma $A 549$ cells through a reactive oxygen species-dependent mitochondrial signaling pathway. Oncol Rep 2010, 23(2):397-403.

52. Chen QY, Lu GH, Wu YQ, Zheng Y, Xu K, Wu LJ, et al: Curcumin induces mitochondria pathway mediated cell apoptosis in A549 lung adenocarcinoma cells. Oncol Rep 2010, 23(5):1285-92.

53. Li R, Ding T, Liu X, Li C: Influence of SB203580 on cell apoptosis and P38MAPK in renal ischemia/reperfusion injury. J Huazhong Univ Sci Technolog Med Sci 2006, 26(1):50-2.

54. Xia Z, Dickens M, Raingeaud J, Davis RJ, Greenberg ME: Opposing effects of ERK and JNK-p38 MAP kinases on apoptosis. Science 1995, 270(5240):1326-31.

55. Owens TW, Valentijn AJ, Upton JP, Keeble J, Zhang L, Lindsay J, et al: Apoptosis commitment and activation of mitochondrial Bax during anoikis is regulated by p38MAPK. Cell Death Differ 2009, 16(11):1551-62.

56. Hu M, Du Q, Vancurova I, Lin X, Miller EJ, Simms HH, et al: Proapoptotic effect of curcumin on human neutrophils: activation of the p38 mitogen-activated protein kinase pathway. Crit Care Med 2005, 33(11):2571-8.

57. Zarubin T, Han J: Activation and signaling of the p38 MAP kinase pathway. Cell Res 2005, 15(1):11-8.

58. Weir NM, Selvendiran K, Kutala VK, Tong L, Vishwanath S, Rajaram M, et al: Curcumin induces G2/M arrest and apoptosis in cisplatin-resistant human ovarian cancer cells by modulating Akt and p38 MAPK. Cancer Biol Ther 2007, 6(2):178-84.

59. Priya S, Sudhakaran PR: Curcumin-induced recovery from hepatic injury involves induction of apoptosis of activated hepatic stellate cells. Indian J Biochem Biophys 2008, 45(5):317-25.
60. Dujic J, Kippenberger S, Hoffmann S, Ramirez-Bosca A, Miquel J, DiazAlperi J, et al: Low concentrations of curcumin induce growth arrest and apoptosis in skin keratinocytes only in combination with UVA or visible light. J Invest Dermatol 2007, 127(8):1992-2000.

61. Tourkina E, Gooz P, Oates JC, Ludwicka-Bradley A, Silver RM, Hoffman S: Curcumin-induced apoptosis in scleroderma lung fibroblasts: role of protein kinase cepsilon. Am J Respir Cell Mol Biol 2004, 31(1):28-35.

62. Scharstuhl A, Mutsaers HA, Pennings SW, Szarek WA, Russel FG, Wagener FA: Curcumin-induced fibroblast apoptosis and in vitro wound contraction are regulated by antioxidants and heme oxygenase: implications for scar formation. J Cell Mol Med 2009, 13(4):712-25.

63. Shu JC, He YJ, LV X, Ye GR, Wang LX: Curcumin prevents liver fibrosis by inducing apoptosis and suppressing activation of hepatic stellate cells. $J$ Nat Med 2009, 63(4):415-20.

64. Lim SJ, Lee YJ, Lee E: p38MAPK inhibitor SB203580 sensitizes human SNU-C4 colon cancer cells to exisulind-induced apoptosis. Oncol Rep 2006, 16(5):1131-5.

65. Zhang X, Shan P, Otterbein LE, Alam J, Flavell RA, Davis RJ, et al: Carbon monoxide inhibition of apoptosis during ischemia-reperfusion lung injury is dependent on the p38 mitogen-activated protein kinase pathway and involves caspase 3. J Biol Chem 2003, 278(2):1248-58

66. Lavoie JN, Lambert H, Hickey E, Weber LA, Landry J: Modulation of cellular thermoresistance and actin filament stability accompanies phosphorylation-induced changes in the oligomeric structure of heat shock protein 27. Mol Cell Biol 1995, 15(1):505-16.

67. Schafer C, Ross SE, Bragado MJ, Groblewski GE, Ernst SA, Williams JA: A role for the p38 mitogen-activated protein kinase/Hsp 27 pathway in cholecystokinin-induced changes in the actin cytoskeleton in rat pancreatic acini. J Biol Chem 1998, 273(37):24173-80.

68. Huot J, Houle F, Marceau F, Landry J: Oxidative stress-induced actin reorganization mediated by the p38 mitogen-activated protein kinase/ heat shock protein 27 pathway in vascular endothelial cells. Circ Res 1997, 80(3):383-92.

69. Bitar KN: HSP27 phosphorylation and interaction with actin-myosin in smooth muscle contraction. Am J Physiol Gastrointest Liver Physiol 2002, 282(5):G894-903.

70. Paul C, Manero F, Gonin S, Kretz-Remy C, Virot S, Arrigo A-P: Hsp27 as a Negative Regulator of Cytochrome c Release 10.1128/MCB.22.3.816834.2002. Mol Cell Biol 2002, 22(3):816-834.

71. Gourlay CW, Ayscough KR: The actin cytoskeleton: a key regulator of apoptosis and ageing? Nat Rev Mol Cell Biol 2005, 6(7):583-9.

72. Brown SB, Bailey K, Savill J: Actin is cleaved during constitutive apoptosis. Biochem J 1997, 323:233-237.

73. Mashima T, Naito M, Tsuruo T: Caspase-mediated cleavage of cytoskeletal actin plays a positive role in the process of morphological apoptosis. Oncogene 1999, 18(15):2423-30.

74. Parcellier A, Brunet M, Schmitt E, Col E, Didelot C, Hammann A, et al: HSP27 favors ubiquitination and proteasomal degradation of p27Kip1 and helps S-phase re-entry in stressed cells. Faseb J 2006, 20(8):1179-81.

75. Parcellier A, Schmitt E, Gurbuxani S, Seigneurin-Berny D, Pance A, Chantome $A$, et al: HSP27 is a ubiquitin-binding protein involved in IkappaBalpha proteasomal degradation. Mol Cell Biol 2003, 23(16):5790-802.

76. Dai T, Patel-Chamberlin M, Natarajan R, Todorov I, Ma J, LaPage J, et al: Heat shock protein 27 overexpression mitigates cytokine-induced islet apoptosis and streptozotocin-induced diabetes. Endocrinology 2009, 150(7):3031-9.

77. Park KJ, Gaynor RB, Kwak YT: Heat shock protein 27 association with the I kappa B kinase complex regulates tumor necrosis factor alpha-induced NF-kappa B activation. J Biol Chem 2003, 278(37):35272-8.

78. Bruey JM, Ducasse C, Bonniaud P, Ravagnan L, Susin SA, Diaz-Latoud C, et al: Hsp27 negatively regulates cell death by interacting with cytochrome c. Nat Cell Biol 2000, 2(9):645-52.

79. Knauf U, Jakob U, Engel K, Buchner J, Gaestel M: Stress- and mitogeninduced phosphorylation of the small heat shock protein $\mathrm{Hsp} 25$ by MAPKAP kinase 2 is not essential for chaperone properties and cellular thermoresistance. Embo J 1994, 13(1):54-60.

80. Preville X, Schultz H, Knauf U, Gaestel M, Arrigo AP: Analysis of the role of Hsp25 phosphorylation reveals the importance of the oligomerization state of this small heat shock protein in its protective function against 
TNFalpha- and hydrogen peroxide-induced cell death. J Cell Biochem 1998, 69(4):436-52

81. Mehlen P, Hickey E, Weber LA, Arrigo AP: Large unphosphorylated aggregates as the active form of hsp27 which controls intracellular reactive oxygen species and glutathione levels and generates a protection against TNFalpha in NIH-3T3-ras cells. Biochem Biophys Res Commun 1997, 241(1):187-92.

82. Kato K, Ito H, Kamei K, Iwamoto I: Stimulation of the stress-induced expression of stress proteins by curcumin in cultured cells and in rat tissues in vivo. Cell Stress Chaperones 1998, 3(3):152-60.

83. Rao CV, Rivenson A, Simi B, Reddy BS: Chemoprevention of colon carcinogenesis by dietary curcumin, a naturally occurring plant phenolic compound. Cancer Res 1995, 55(2):259-66.

84. Ukil A, Maity S, Karmakar S, Datta N, Vedasiromoni JR, Das PK: Curcumin, the major component of food flavour turmeric, reduces mucosal injury in trinitrobenzene sulphonic acid-induced colitis. Br J Pharmacol 2003, 139(2):209-18.

85. Selvam C, Jachak SM, Thilagavathi R, Chakraborti AK: Design, synthesis, biological evaluation and molecular docking of curcumin analogues as antioxidant, cyclooxygenase inhibitory and anti-inflammatory agents. Bioorg Med Chem Lett 2005, 15(7):1793-7.

86. Huang MT, Lysz T, Ferraro T, Abidi TF, Laskin JD, Conney AH: Inhibitory effects of curcumin on in vitro lipoxygenase and cyclooxygenase activities in mouse epidermis. Cancer Res 1991, 51(3):813-9.

87. Song $X$, Lin HP, Johnson AJ, Tseng PH, Yang YT, Kulp SK, et al: Cyclooxygenase-2, player or spectator in cyclooxygenase-2 inhibitorinduced apoptosis in prostate cancer cells. J Natl Cancer Inst 2002, 94(8):585-91

88. Li B, Castano A, Hudson TE, Nowlin BT, Lin SL, Bonventre JV, Swanson KD, Duffield JS: The melanoma-associated transmembrane glycoprotein Gpnmb controls trafficking of cellular debris for degradation and is essential for tissue repair. FASEB J 2010.

89. Kurien BT: Inhibition of $\mathrm{p} 300$ and nuclear factor-kappaB by curcumin and its role in diabetic nephropathy. Nutrition 2009, 25(9):973-4, author reply 975-6.

90. Meyer MH, Meyer RA Jr, Gray RW, Irwin RL: Picric acid methods greatly overestimate serum creatinine in mice: more accurate results with highperformance liquid chromatography. Anal Biochem 1985, 144(1):285-90.

91. Natarajan R, Gu JL, Rossi J, Gonzales N, Lanting L, Xu L, et al: Elevated glucose and angiotensin II increase 12-lipoxygenase activity and expression in porcine aortic smooth muscle cells. Proc Natl Acad Sci USA 1993, 90(11):4947-51.

92. Kang SW, Adler SG, Nast CC, LaPage J, Gu JL, Nadler JL, et al: 12lipoxygenase is increased in glucose-stimulated mesangial cells and in experimental diabetic nephropathy. Kidney Int 2001, 59(4):1354-62.

93. Reddy MA, Adler SG, Kim YS, Lanting L, Rossi J, Kang SW, et al: Interaction of MAPK and 12-lipoxygenase pathways in growth and matrix protein expression in mesangial cells. Am J Physiol Renal Physiol 2002, 283(5) F985-94.

94. Kim YS, Reddy MA, Lanting L, Adler SG, Natarajan R: Differential behavior of mesangial cells derived from 12/15-lipoxygenase knockout mice relative to control mice. Kidney Int 2003, 64(5):1702-14.

95. Began G, Sudharshan E, Appu Rao AG: Inhibition of lipoxygenase 1 by phosphatidylcholine micelles-bound curcumin. Lipids 1998, 33(12):1223-8.

96. Skrzypczak-Jankun E, McCabe NP, Selman SH, Jankun J: Curcumin inhibits lipoxygenase by binding to its central cavity: theoretical and X-ray evidence. Int J Mol Med 2000, 6(5):521-6.

97. Antonipillai I, Horton R, Natarajan R, Nadler J: A 12-lipoxygenase product of arachidonate metabolism is involved in angiotensin action on renin release. Endocrinology 1989, 125(4):2028-34.

98. Ma J, Natarajan R, LaPage J, Lanting L, Kim N, Becerra D, et al: 12/15lipoxygenase inhibitors in diabetic nephropathy in the rat. Prostaglandins Leukot Essent Fatty Acids 2005, 72(1):13-20

\section{Pre-publication history}

The pre-publication history for this paper can be accessed here: http://www.biomedcentral.com/1472-6882/10/67/prepub doi:10.1186/1472-6882-10-67

Cite this article as: Ma et al:: Curcumin activates the p38MPAK-HSP25 pathway in vitro but fails to attenuate diabetic nephropathy in DBA2J mice despite urinary clearance documented by HPLC. BMC Complementary and Alternative Medicine 2010 10:67.

\section{Submit your next manuscript to BioMed Central and take full advantage of:}

- Convenient online submission

- Thorough peer review

- No space constraints or color figure charges

- Immediate publication on acceptance

- Inclusion in PubMed, CAS, Scopus and Google Scholar

- Research which is freely available for redistribution 